\title{
Convergent catastrophes and the termination of the Arctic Norwegian Stone Age: A multi-proxy assessment of the demographic and adaptive responses of mid- Holocene collectors to biophysical forcing
}

The Holocene

2019, Vol. 29(II) 1782-1800

(C) The Author(s) 2019

Article reuse guidelines:

sagepub.com/journals-permissions DOI: $10.1177 / 0959683619862036$ journals.sagepub.com/home/hol

(SAGE

\author{
Erlend Kirkeng Jørgensen' (iD) and Felix Riede ${ }^{2}$
}

\begin{abstract}
Using multiple archeological and paleoenvironmental proxies, this paper makes the case for a climate-induced convergent catastrophe among the human population of terminal Stone Age Arctic Norway. We show that climatic changes correlate with the termination of the so-called Gressbakken phase (4200$3500 \mathrm{cal} \mathrm{BP}$ ), and unpack the middle-range mechanisms linking the Gressbakken termination to contemporaneous changes in the biophysical environment. We show that what was a Holocene extreme, and likely volcanically-induced, climate deterioration around 3550 cal BP coincided with a population decline as reflected in the frequency of radiocarbon-dated archeological sites along with major changes in material culture and settlement pattern. Together, these proxies suggest a return to forms of social and economic organization based on lower population densities, higher residential mobility, and reduced locational investments. In establishing the middle-range ecological mechanics mediating these changes into archeologically observable patterns, the results indicate that the Gressbakken termination was the result of a particularly unstable climate period characterized by regional paludification, increased effective precipitation, forest decline, and likely impacts on reindeer populations and their migratory behavior, with drastic human implications. We argue for a convergent catastrophe-scenario in which a series of hardships between 4000 and 3500 cal BP exceeded the adaptive mitigation capabilities of the contemporaneous Arctic Norwegian population. Our study supports the notion that increased sedentism and locational investment actually increases vulnerability in the face of rapid biophysical change and contributes to the growing database of past human ecodynamics that speak to current socioecological concerns.
\end{abstract}

\section{Keywords}

adaptive strategies, Arctic Norway, climate forcing, Gressbakken phase, human ecodynamics, palaeodemography, resilience, risk mitigation, tephrochronology

Received 29 January 2019; revised manuscript accepted 25 May 2019

\section{Introduction}

The societal impacts of past climatic and environmental changes and events - and the implications of these for future trajectories of social change (e.g. Costanza et al., 2007) - have been in the limelight of recent research (Butzer, 2012; Cooper and Sheets, 2012; Middleton, 2017; Weiss and Bradley, 2001). Although controversy persists, much of this research suggests that past environmental changes frequently precipitated societal 'moments of crisis' (Tipping et al., 2012: 9). Within this line of investigation, recent high-resolution paleoclimatic data and modeling have revealed that volcanic forcing of climatic variability led to important downstream cultural changes in the state-level societies of the 6th and subsequent centuries CE across Europe (Büntgen et al., 2016; Toohey et al., 2016). Analyses comparing different archeological and climatic proxies indicate complex and substantive causal pathways connecting distant volcanic eruptions, temperature changes, and societal consequences including economic, political, and religious transformations (Gräslund and Price, 2012; Høilund Nielsen, 2005; Loveluck et al., 2018; Nordvig and Riede, 2018; Price and Gräslund, 2015). Parallel to this focus on the decline and collapse - however defined (cf. Middleton, 2017)
- of complex societies, major research efforts have also been invested in elucidating the impact of climate shifts and ecosystem restructuration on various Holocene hunter-gatherer populations (Robinson and Riede, 2018).

Given an exceptionally well-curated and well-researched archeological record combined with an abundance of paleoenvironmental proxies, it has been suggested that northern Europe is 'an extraordinary laboratory for the investigation of human colonization and adaptation' (Price, 1991: 185). Despite such programmatic claims, the archeological record of Northern Norway

\footnotetext{
'Department of Archaeology, History, Religious Studies and Theology, UiT - The Arctic University of Norway, Norway

${ }^{2}$ Laboratory for Past Disaster Science, Department of Archaeology and Heritage Studies, Aarhus University, Denmark

\section{Corresponding author:}

Erlend Kirkeng Jørgensen, Department of Archaeology, History, Religious Studies and Theology, UiT - The Arctic University of Norway, Postbox 6050 Langnes, 9037 Tromsø, Norway.

Email: erlend.k.jorgensen@uit.no
} 
has not been interrogated in any depth with regard to such past impacts and their human responses. Located well above the Arctic Circle, northern Norwegian environments are comparatively harsh and human population densities low, as clearly indicated by population estimates based on historic census data (Hansen, 2009; Hood, 2015). Traditionally, however, the population history of prehistoric Arctic Norway has mostly been assumed to be continuous, with internal development being the main driver of change. This has recently been challenged by palaeodemographic modeling suggesting several marked boom and bust cycles (Jørgensen, 2018), raising the pressing question of what possible causes may stand behind these population dynamics. This is particularly pertinent when considering that one such cycle corresponds to the iconic Gressbakken phase. Traditionally dated to 4200-3800 cal BP, it has become iconic through the rich archeological record found across northernmost Fennoscandia and northwestern Russia, including large semi-subterranean houses, substantial refuse middens, and a rich and diverse osseous industry. Against the background of this material effervescence, the extensively investigated Gressbakken phase is thought to reflect heightened levels of sedentism and greater population size and density, followed by a radical reduction in those demographic parameters along with its termination. These factors make the Gressbakken phase uniquely interesting, as they allow testing of more generalized anthropological models for the explanation of cultural change, risk-management, and adaptive strategies among hunter-gatherers. We present a first, rigorous dating scheme of the Gressbakken phase based on a compilation of all existing, directly dated Gressbakken houses. As the termination was seemingly dramatic and wide-spread, we here review the possible impacts of abrupt and persistent climate forcing on what has been termed the most socially complex hunter-gatherers of North Norwegian prehistory (Schanche, 1994: 181). Previous portrayals of the Gressbakken termination have emphasized a move from complex semi-sedentary groups to smaller and mobile units, suggesting that increasing social stress following inequality eventually brought about this 'collapse' (Myrvoll, 1992: 183; Olsen, 1994: 131; Schanche, 1988, 1994). Importantly, the alleged complexity of the Gressbakken phase and its decline allows for a local test of the hypothesized reduction in resilience following increased societal complexity, reduced residential mobility, and locational investment, as originally formulated by Sheets $(2001,2012)$. The recent accumulation of local and highly resolved climate proxy data of direct relevance to human socioecological issues enables us to make a systematic review of the environmental setting of the Gressbakken phase and to better evaluate hypotheses of potential climate-induced demographic and social change. Interestingly, previous studies have placed substantial emphasis on the Gressbakken phenomenon as a canvas for interpretations concerning symbolism and social complexity, side-lining the importance of environmental factors in cultural change (Hood, 2019b: 21; Olsen, 1994; Schanche, 1994). It is therefore all the more important to investigate afresh the human ecodynamics pertaining to the Gressbakken phase. Here, we attempt such an investigation by compiling the first comprehensive radiocarbon record for the Gressbakken phase, and by analyzing this database as a first-pass proxy for human population activity. This demographic proxy is then judiciously combined with highly resolved climatic proxies as well as material culture evidence. We show that significant reductions in human presence correlate with similarly significant climatic and environmental perturbations and, as a consequence, with cultural changes. Against the background of these observations, we evaluate what mechanisms may account for the demographic dynamics around $3550 \mathrm{cal} \mathrm{BP}$ and thus contribute to a wider anthropological and human ecodynamic research agenda on human adaptive responses, risk-mitigation strategies, and past disaster science. Based on the present ecodynamic review, we also suggest a revision of the established chronology for the Gressbakken phase, proposing a new terminal date at $3500 \mathrm{cal}$ $\mathrm{BP}$ - relating to regional environmental perturbations as well as continental-scale environmental and cultural upheavals.

\section{The Gressbakken phase: Background and framing}

The Gressbakken phase, named after the eponymous site in the Varanger Fjord (eastern Finnmark), is one of the most thoroughly investigated phenomena of North Norwegian prehistory. It has formally been defined as a spatiotemporal phase, on the basis of its distinct cultural horizon in the Northern Fennoscandian archeological sequence (Hood, 2016). Most Gressbakken phase sites are coastal cluster sites of multiple dwelling structures organized in rows, and are generally characterized by relatively rich material, including extensive refuse middens, semi-subterranean houses of substantial size, osseous tools and, more rarely, human remains. Chronologically, the Gressbakken phenomenon constitutes the final phase of the Younger Stone Age of Northern Norway, at the onset of the early Metal Period. It is traditionally dated to 4200-3800 cal BP (Helskog, 1980, 1984; Olsen, 1994: 72; Schanche, 1995: 181).

We here focus on the Gressbakken phase as a tradition with particular emphasis on housing structures - in line with the common use of houses as a primary criterion for defining the period as a distinct horizon in the archeological record (cf. Simonsen, 1979). Gressbakken houses have been defined as a typologically distinct tradition, based on morphological and architectural features listed in Table 1 and some of which are illustrated in Figure 1. The previously derived and still highly influential typology of changes in house-building throughout the Younger Stone Age of Northern Norway is presented in Table 1. However, current data suggest underappreciated variation in house types. For example, it has been demonstrated that a variety of both the assumed later Mortensnes and earlier Nyelv houses were used throughout the Gressbakken phase (Niemi and Oppvang, 2018; Oppvang, 2018).

The Gressbakken phase house phenomenon has been portrayed as particular to eastern Finnmark (Simonsen, 1996: 124), based on the observation of on average larger house-floors $\left(30 \mathrm{~m}^{2}\right)$ and more numerous, row-organized houses, compared to the smaller $\left(20 \mathrm{~m}^{2}\right)$ and mostly minor house-clusters in western Finnmark (Damm et al., 2019). Nonetheless, similarities across Finnmark have been pointed to on various occasions (Andreassen, 1985: 145; Schanche, 1994: 58; Simonsen, 1996: 130). Data accumulated since the early 1990 s seem to cement the picture of shared trends across Finnmark during this period, consisting of increasing settlement sizes, richer finds, larger and more deeply dug pit houses with two hearths and, in some instances, annexes. Cognizant of potential micro-regional variability, we here apply the term Gressbakken phase to include all of Finnmark. We believe this is justified due to the identification of similar sites outside the core area of Varanger, both on the Russian Kola Peninsula (east), in Porsanger (central Finnmark), and at Sørøya (western Finnmark). Previous syntheses have remarked upon the comparable developments also in western Finnmark (increased house sizes, double hearths, rich inventories), but have been reluctant to classify the trends outside the Varanger Fjord area as part of the Gressbakken phase owing to the lack of other diagnostic morphological house features (Olsen, 1994: 75; cf. Andreassen, 1985). Such cases are now known from western Finnmark, such as the Tollevika site in Alta (Bell, 2004), as well as at Slettnes VC (Hesjedal et al., 1996: 136).

Outside Finnmark County, the $4200-3800$ cal BP interval is less well investigated. Different geomorphological conditions 
Table I. Traditional typology of Younger Stone Age houses in Northern Norway.

Traditional house typology of Younger Stone Age Northern Norway (primarily eastern Finnmark)

\begin{tabular}{|c|c|c|c|}
\hline House type & $\begin{array}{l}\text { Assumed age } \\
\text { span, cal BP }\end{array}$ & Characteristics & Key references \\
\hline Karlebotn type & $6500-5000$ & $\begin{array}{l}\text { Small, round houses of slight subterranean excavation, with one central hearth and no } \\
\text { marked entrances. }\end{array}$ & Simonsen (1979: 367) \\
\hline Nyelv type & $5200-4500$ & $\begin{array}{l}\text { Medium-sized, rectangular, and slightly excavated floor plan with two central hearths } \\
\text { separated by cooking-stones, and without marked entrances. }\end{array}$ & $\begin{array}{l}\text { Olsen (1994: 7I) and } \\
\text { Simonsen (1979: } 375)\end{array}$ \\
\hline Gressbakken type & $4500-3800$ & $\begin{array}{l}\text { Large, rectangular, and deeply excavated floor plan, with two central and symmetrical } \\
\text { hearths separated by cooking-stones. Large middens and wall embankments, as well as } \\
\text { multiple entrances and annexes. }\end{array}$ & $\begin{array}{l}\text { Schanche (1994) and } \\
\text { Simonsen (196I) }\end{array}$ \\
\hline Mortensnes type & $3800-3000$ & $\begin{array}{l}\text { Medium-sized, square (sub-rectangular), and deeply excavated floor plan, with one } \\
\text { asymmetrically positioned hearth and lacking marked entrances. }\end{array}$ & $\begin{array}{l}\text { Johansen and Odner } \\
\text { (1968), Olsen (1994: } \\
\text { II3), and Schanche } \\
\text { (I988: I3I) }\end{array}$ \\
\hline
\end{tabular}

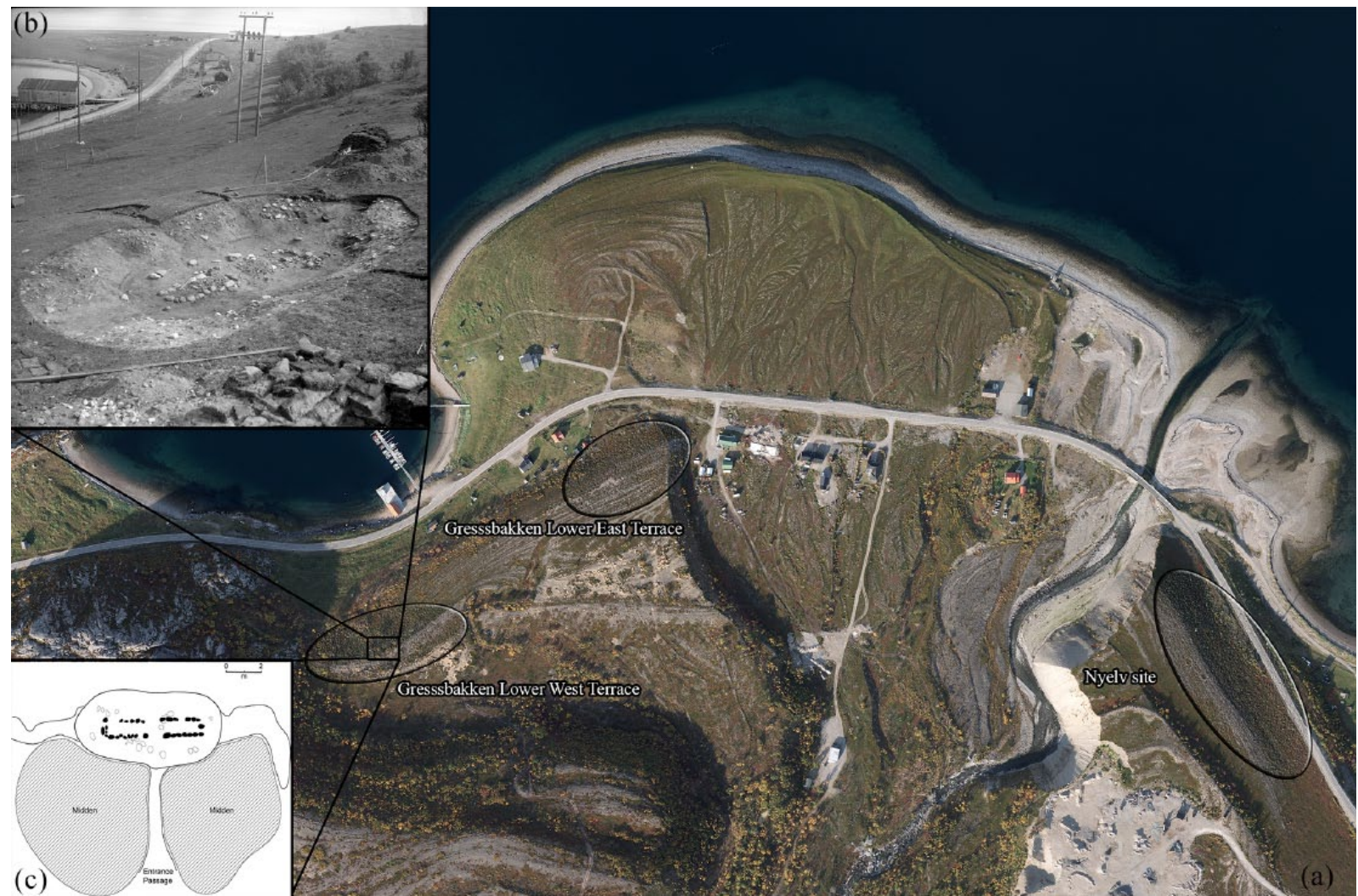

Figure I. (a) Satellite photo of the Gressbakken type site and its position on top of a glaciofluvial delta (from GeoNorge.no). (b) Original photo of House 3 under excavation, from Simonsen (196I: 127), digital remastering by Sveinulf Hegstad at Tromsø Museum. (c) Plan drawing of House 3, from Hood and Melsæther (2016). Reproduced with permission.

may be partly responsible, as the preservation and discovery of Gressbakken sites becomes less likely outside the Varanger Fjord - as its sheltered and lower energy environs are more suitable for sedimentary deposition when compared to central and western coastal Northern Norway, as demonstrated in Figure 1. Large, Gressbakken-like houses with similar diagnostic architectural features have been identified on favorable geomorphological sites in western Finnmark, for example, Båtnes and Hanselv. This is in addition to previously known and partly investigated sites at both Sørøya island in western Finnmark, such as at Slettnes, Sandbukt, Risvåg, and Markeila (Simonsen, 1964), and the Porsanger Fjord area in central coastal Finnmark (Oppvang et al., 2018; Schanche, 1994: 59).

It has previously been asserted that significant and widespread changes correlated with the disappearance of the classic Gressbakken houses, such as increased residential mobility, an economic restructuration toward terrestrial resource exploitation, mainly to maintain trading networks toward the east in exchange for metal products, major changes in rock art depictions resembling Southern Scandinavian Bronze Age motifs, and a markedly less ornate material culture compared with the Gressbakken phase (Myrvoll, 1992; Olsen, 1994: 127-129). Yet, no coherent and testable hypothesis for what may have caused these dramatic changes has so far been offered.

\section{Complex collectors during the Gressbakken phase - Predictions for socio-ecological resilience}

Following Binford (1980), hunter-gatherers can be placed somewhere along a forager-to-collector spectrum, where the collectorend is characterized by large and often quasi-sedentary groups, complex social structures, investment into tended and untended 


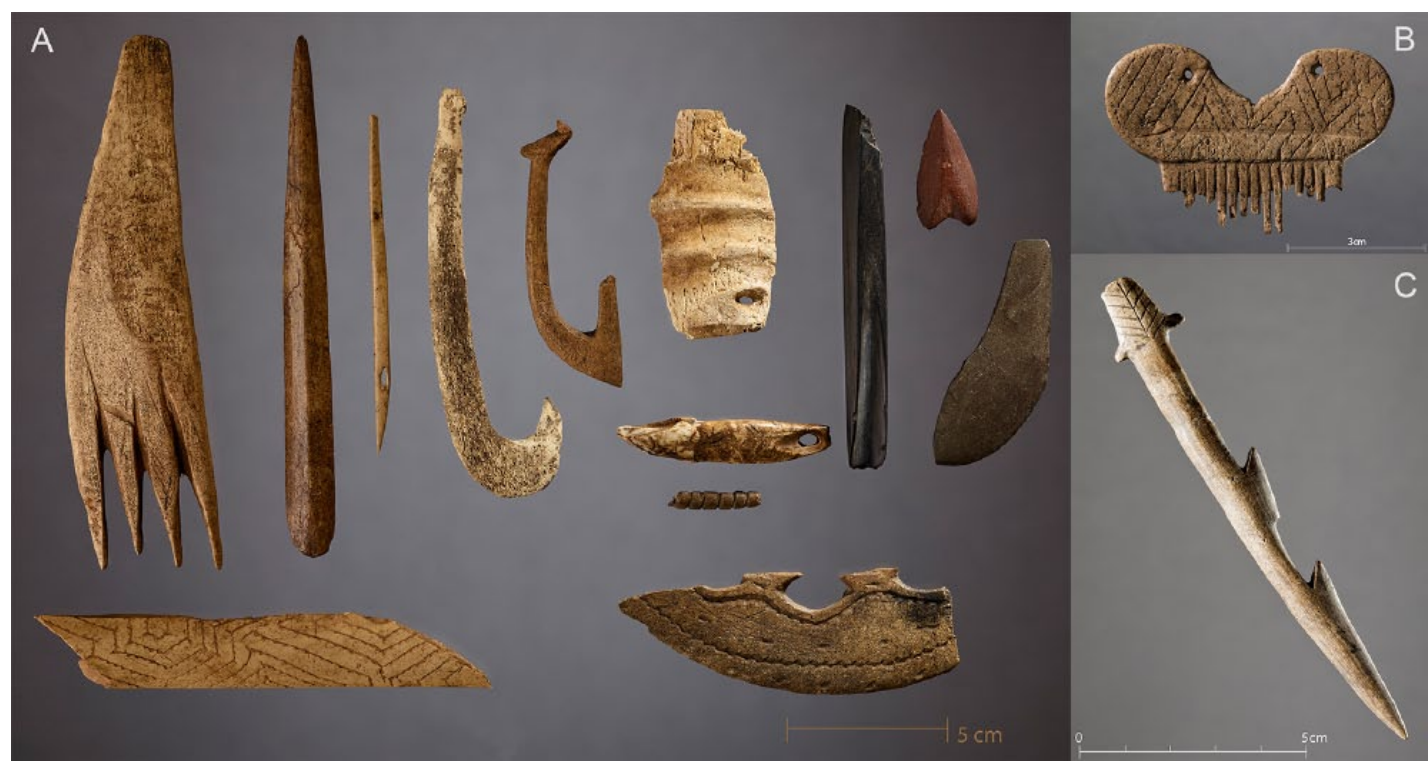

Figure 2. Selection of semi-diagnostic object classes from the Gressbakken phase.All objects stem from the classic Gressbakken site, House 4 (Ts5526). (a) From upper left to lower right: I. Bone comb (hx); 2. Bone projectile point (kn); 3. Bone needle (ct); 4 . Fish hook, rounded base and straight, perforated attachment head (hc); 5. Fish hook, angled base and transverse attachment head (bæ); 6. Fish line davit block (hs); 7. Miniature, oblong slate chisel (ge); 8. Small, fluted slate arrowhead of the Sunderøy type (dz); 9. Miniature slate knife (bo); 10. Perforated dog/fox tooth pendant (if); I I. Bone beads, still attached (is); I 2. Asymmetric, line and dot ornamented bone piece, representative of much ornamented bone industry (iv); and 13. Ornamented bone plate, potential ulu-like artifact (hø). (b) Ts5525ds ornamented bone comb. (c) Ts5526ak harpoon. Photo by Mari Karlstad,Tromsø Museum.

facilities, often exotic goods and raw materials, and sometimes social differentiation and higher population densities (Kelly, 2013). Such collector-like socio-economic constellations emerge in ecological settings offering concentrated and more or less predictable resources.

The issue of social complexity has long been debated with respect to the Gressbakken phase, with strong emphasis being put on the collector-like properties in evidence. The often spectacular and well-preserved archeological features and artifacts associated with the Gressbakken phase (Figure 2) have resulted in extensive archeological investigations (Nummedal, 1937; Schanche, 1994; Simonsen, 1961), as well as analyses of the otherwise very rare faunal data (Hodgetts, 2010; Renouf, 1984, 1989), midden deposits (Helama and Hood, 2011; Hood and Helama, 2010; Hood and Melsæther, 2016) and their geoarcheological preservative properties (Martens et al., 2017). These factors have been used to argue that the Gressbakken phase marked the heyday of social complexity within the Stone Age of Northern Norway. The characteristics used to define the Gressbakken phase as distinctly more complex than both the preceding as well as the following phases are summarized in Table 2. Gressbakken phase sites have been interpreted as representing large and hierarchically organized Stone Age communities that are at least semi-sedentary, with substantial cooperation in the context of large marine mammal exploitation. They are most commonly framed in direct analogy to the American Coast Salish (Schanche, 1995: 184; cf. Angelbeck, 2016; Drucker, 1951; Gronenborn, 2003; Suttles and Sturtevant, 1990). Olsen (1994: 91; following Renouf, 1989), for instance, suggested that the presence of whale and Delphinidae bones in some middens together with the (assumed) increase in settlement size and increasing number of dwelling structures at each site during the Gressbakken phase could be a corollary of whale hunting requiring the careful coordination of group labor.

Critics, however, have suggested that the case for social complexity in Northern Norway has been overstated (Hood, 1995, $2019 b)$. This is partly a consequence of high-precision re-dating of elements fundamental to the interpretation of the Gressbakken phase as particularly complex; this work has resulted in copper implements, late comb ceramics, anthropomorphic figurines, and ornamented osseous tools now being shifted back to $5000 \mathrm{cal}$ BP (Hood and Helama, 2010). The Gressbakken phase may therefore be more of a culmination of longer term developments than a short-term fluorescence. Regardless of material culture trends, regional demographic modeling suggests a distinct population growth cycle that corresponds to the Gressbakken phase (Jørgensen, 2018). The mechanisms responsible for this event have yet to be fully explored.

The Gressbakken phase has furthermore been presented as being of local origin and its emergence and development primarily driven by internal social dynamics (Schanche, 1994: 207208). A systematic attempt at regional contextualization clearly indicates, however, that the core area of the house tradition is, in fact, situated in Northwestern Russia (Hood, 2019b: 148). Largescale field surveys of the Kola Peninsula have identified a large number of house pits morphologically identical to those of the Norwegian Gressbakken phase, and with corresponding material culture (Kolpakov and Murashkin, 2016). The few existing dates from Gressbakken-like houses on the Kola Peninsula confirm a correspondence with the Gressbakken phase elsewhere (Helskog et al., in press; Hood, 2019b: 151). The assumed variation in house types and settlement pattern along an east-west gradient in Finnmark may therefore result from a clinal distribution of the Gressbakken phenomenon, as is to be expected with increased distance from a core area in Russia. In sum, the Gressbakken phenomenon appears to have developed first outside of Northern Norway and to have developed over a longer period than previously assumed. Its termination, however, stands out as abrupt and comprehensive.

Against the canvas of current data, we shy away from strictly viewing the Gressbakken phase as reflecting 'complex' huntergatherers on par with classic analogs of the ethnographic present. Still, we remain confident in attributing to it higher population size and density, near-sedentism, and increased investments in tended and untended facilities, thus meeting some of the requirements traditionally listed in favor of complexity among northern maritime foragers (cf. Rowley-Conwy and Piper, 2016). Although 
Table 2. Often-cited indicators of heightened complexity during the Gressbakken phase.

\begin{tabular}{|c|c|c|}
\hline \multirow[t]{2}{*}{ No. } & Complexity indicators & \multirow[t]{2}{*}{ Key references } \\
\hline & Characteristic & \\
\hline 1 & $\begin{array}{l}\text { Large communal sites occupied by a large population (estimated } 200 \text { per } \\
\text { larger site) }\end{array}$ & Schanche (1994: 177, 1995: 183), cf. Helskog (1984) \\
\hline 2 & Sedentism or near-sedentism & Olsen (1994: 85) and Schanche (1995: I8I), cf. Engelstad (1984) \\
\hline 3 & Hierarchical social organization & $\begin{array}{l}\text { Olsen (1994: 92) and Schanche (1988: 188, 1989, 1995), cf. Simon- } \\
\text { sen (1972: 164) }\end{array}$ \\
\hline 4 & Economic intensification & Renouf (1989: 191), cf. Hodgetts (2010) \\
\hline 5 & $\begin{array}{l}\text { Deeply excavated }(<1.3 \mathrm{~m}) \text {, semi-subterranean houses of substantial size } \\
\text { (average } 25 \mathrm{~m}^{2}, \max <70 \mathrm{~m}^{2} \text { ) }\end{array}$ & Simonsen (1979: 37I), cf. Engelstad (1985: 83) and Hood (2019b: 8) \\
\hline 6 & Midden accumulation & Hodgetts (2010) and Renouf (1988) \\
\hline 7 & Houses organized in rows & Schanche (1994: 72) and Simonsen (196I) \\
\hline 8 & Architectural features of houses such as multiple entrances and annexes & $\begin{array}{l}\text { Schanche (1995: 180) and Simonsen (1961, 1979), cf. Engelstad } \\
(1985: 83,1988)\end{array}$ \\
\hline 9 & $\begin{array}{l}\text { Mostly two large, stone-lined, symmetrical fireplaces separated by a mid- } \\
\text { section often densely packed with fire-cracked rocks }\end{array}$ & Schanche (1994) and Simonsen (196I, 1979: 17I) \\
\hline 10 & $\begin{array}{l}\text { Burials in cairns and middens. Total of II individuals at original Gressbakken } \\
\text { site. }\end{array}$ & Henriksen (2003) and Olsen (1994: 88) \\
\hline 11 & Increased ornamentation of osseus industry & Olsen (1994: 90) and Myrvoll (1992) \\
\hline 12 & $\begin{array}{l}\text { Increase in exotic and prestigious imports (copper from the east, flint } \\
\text { artifacts from the south or east) }\end{array}$ & Olsen (1994: 125) \\
\hline 13 & $\begin{array}{l}\text { Ritual intensification reflected in anthropomorphic figurines and other ritual } \\
\text { paraphernalia }\end{array}$ & Olsen (1994:89) and Schanche (1994: 184, 1998) \\
\hline
\end{tabular}

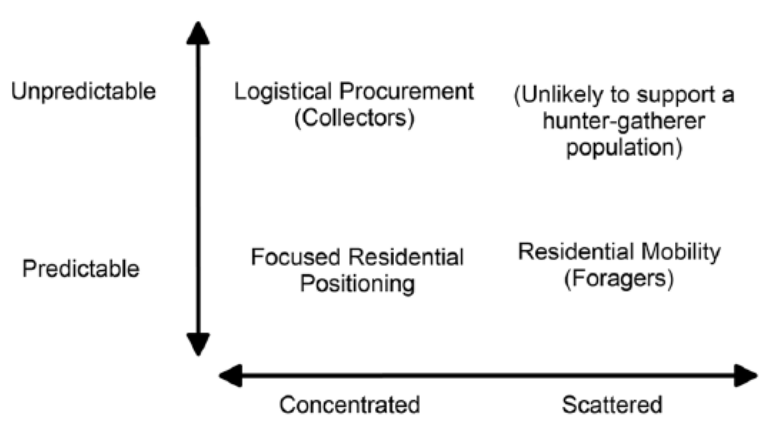

Figure 3. Expected hunter-gatherer mobility strategies in relation to selected resource distribution characteristics. Redrawn from Whallon (2006: 260).

increased social complexity often follows from such demographic conditions, we are not able to empirically demonstrate such complexity (cf. Hawkes, 1954). Nonetheless, we suggest that a number of specific albeit not unique properties of the Gressbakken phase mark it as some way toward the collector-end of the adaptive spectrum (cf. Keeley, 1988).

How, then, should we understand the seemingly sudden changes at the termination of the Gressbakken phase occurring across the spectrum of economy, settlement pattern, architecture, and material culture - all with attendant implications for timescheduling, knowledge transmission, mobility, fertility and their demographic corollaries? Whallon (2006) has presented a useful if static matrix within which forager societies can broadly be placed (Figure 3). Their economic organization references the spatiotemporal distribution and predictability of key resources. As a result of substantial climate change and redistribution of biogeography, forager populations are forced toward other forms of social and economic organization. Of crucial importance here is the prediction by resilience theory that increased locational investments and higher degrees of sedentism - the hallmarks of collector systems - would result in reduced resilience in the face of environmental perturbations. Multiple studies report findings in accord with these predictions (Fitzhugh, 2012; Fitzhugh et al., 2016; Redman and Kinzig, 2003; Sheets, 2001). If, then, the Gressbakken phase did exhibit such collector-like qualities, it may arguably have been susceptible to environmental stressors, especially if multiple and difficult-to-predict stressors compounded each other, resulting in what Moseley (1999: 59) termed a 'convergent catastrophe'.

Related to the Whallon model, Halstead and O'Shea (1989) predicted a set of risk-mitigation strategies employed by huntergatherers forced further along either the $X$ or $Y$ axis by environmental stressors: economic diversification, increased residential mobility, storage and mass processing of bulk resources, as well as exchange networks and reciprocal social relations with populations reliant on different resources. The archeological effects of such mitigation strategies, as observed for the Gressbakken termination, are reviewed in the discussion.

\section{Materials and methods}

\section{Palaeodemography}

Since the suggestion that radiocarbon dates can be used as a population proxy (Haynes, 1969; Holdaway and Porch, 1995; Kirch, 1980; Rick, 1987), considerable efforts have been spent on corroborating, criticizing, and qualifying this approach (Contreras and Meadows, 2014; Surovell and Brantingham, 2007; Surovell et al., 2009; Williams, 2012). We here follow Edinborough et al. (2017) in accepting the general usefulness of this methodology for highlighting significant palaeodemographic fluctuations. More specifically with regard to Northern Europe, it has been argued that foragers as well as farmers underwent considerable demographic fluctuations and that these often coincided with climatic or environmental changes (Riede, 2009a, 2009b; Shennan and Edinborough, 2007; Tallavaara and Seppä, 2012; Tallavaara et al., 2010) or, as Tipping et al. (2012) put it, 'moments of crisis'. Drawing on Binford (2001), we argue that climate affects net productivity and hence carrying capacity, which in turn structures 


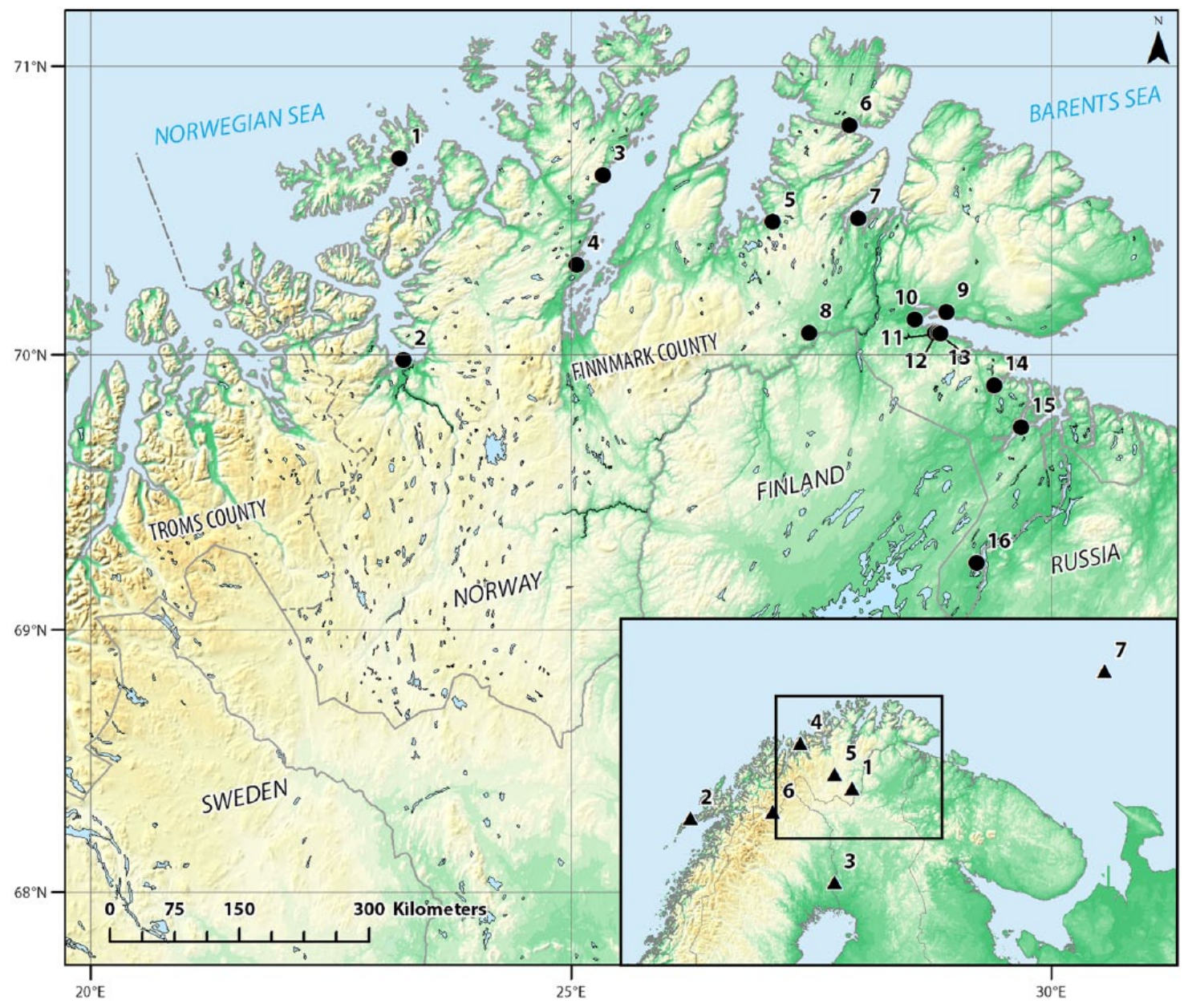

Figure 4. Area map plotting the location of the dated Gressbakken sites, providing data in this paper: I. Sandbukt, 2. Tollevika, 3. Skarvbergvka, 4. Tverrnes, 5. Leirpollen, 6. Iversfjord, 7. Torhop, 8. Laksjohka, 9. Bergeby, I0. Karlebotn, I I.Advik, I2. Gressbakken, I3. Nyelv, I4. Valen, I5. Kalkkilebukt, and 16. Storsteinneset. Many more Gressbakken sites are known, yet lack direct dates and are thus excluded from the map. The small inset map demonstrates the location of climate proxies discussed in this paper; numbers correspond to their description in Table 3. Basemap data: ESRI, Geodatastyrelsen, The Norwegian Mapping Authority, The National Land Survey of Finland, and Airbus Defence and Space $\mathrm{GmbH}$. Map by Johan Eilertsen Arntzen, UiT.

life-history decisions. Cumulatively, such decisions result in specific demographic patterns. With all the caveats of preservation and research bias in mind, we here present a radiocarbon date proxy record for palaeodemographic changes in Northern Norway for the period covering the Gressbakken phase.

For the specific purpose of investigating the occupation intensity of typologically distinct Gressbakken sites, we present the first rigorous dating scheme for the Gressbakken phase (see SI for radiocarbon data and site information, available online). The dates ( $n=107$, combined into 74 bins) were collected from 58 directly dated Gressbakken houses exhibiting typical morphological traits from across Finnmark County (Figure 4). They were then modeled as a summed probability distribution (SPD), following the procedure described in Dye and Komori (1992), Grove (2011), Ramsey (2017), and Williams (2012).

The data used for the regional, demographic background models are based on the North Norwegian Radiocarbon Record, of which the main results have already been presented elsewhere (Jørgensen, 2018). In order to explore any potential variation on settlement pattern as a response to the Gressbakken termination, we also modeled inland population presences on the basis of $n=$ 115 dates, combined into 88 bins of 200 -year intervals in order to normalize the effect of overrepresented sites. Dates obtained from pit-fall features are excluded, both as they provide inherently unreliable results and because they do not track habitation activity which is the matter at hand. The inland area has been significantly less densely investigated, but is included in an attempt to capture settlement dynamics across the region.

All analyses were performed using the Rcarbon package in the $\mathrm{R}$ software environment (Bevan and Crema, 2018; R Development Core Team, 2015). Monte-Carlo simulation tests (Shennan, 2013; Timpson et al., 2014) were performed for both background models, as they contribute new (inland model) or minor revisions (regional model) of previously published models (Jørgensen, 2018) following data revision and methodological development. The results of which can be viewed in the SI (available online).

\section{Paleoenvironment}

In order to evaluate the environmental setting of the Gressbakken phase, we assembled a diverse suite of relevant mid-to-late-Holocene climate proxy records covering the time frame of 6000-2000 cal BP (Table 3). It has already been demonstrated that general northern hemispheric climate reconstructions based exclusively on Greenlandic ice-cores are of less relevance to the climate development in our study area than previously believed due to opposite effects of the North Atlantic Oscillation (Berben et al., 2017; Dawson et al., 2003; Hurrell, 1995; Perner et al., 2015). It is therefore vital that high-resolution and multi-scalar climate data reflecting local-to-regional-scale changes are employed when the aim is to juxtapose these to human demographic and technological responses. Fortunately, Northern Fennoscandia is 
Table 3. Climate records employed for paleoenvironmental review.

\begin{tabular}{|c|c|c|c|c|c|c|c|c|c|c|c|}
\hline No. & Site & $\begin{array}{l}\text { Core } \\
\text { name }\end{array}$ & $\begin{array}{l}\text { General } \\
\text { location }\end{array}$ & $\begin{array}{l}\text { Latitude } \\
\left({ }^{\circ}\right)\end{array}$ & $\begin{array}{l}\text { Longitude } \\
\left({ }^{\circ}\right)\end{array}$ & $\begin{array}{l}\text { Elevation } \\
\text { (m a.s.l.) }\end{array}$ & Source & Proxy & $\begin{array}{l}\text { Resolution } \\
\text { mean (year) }\end{array}$ & Function in climate review & Citation \\
\hline I & $\begin{array}{l}\text { Lapland, } \\
\text { regional }\end{array}$ & Lapland & $\begin{array}{l}\text { N Fen- } \\
\text { noscandia }\end{array}$ & 69.0 & 25.0 & - & Tree & Ring width & I & $\begin{array}{l}\text { High-resolution, regional ter- } \\
\text { restrial baseline }\end{array}$ & $\begin{array}{l}\text { Helama et al. } \\
(2010)\end{array}$ \\
\hline 2 & Rystad & $\begin{array}{l}\text { Rystad } \\
\text { I }\end{array}$ & N Norway & 68.24 & 13.78 & 40 & Peat & $\begin{array}{l}\text { Humifica- } \\
\text { tion index }\end{array}$ & 30 & $\begin{array}{l}\text { Indicator of temperature } \\
\text { and precipitation combined } \\
\text { - evapotranspiration - in the } \\
\text { outermost western coast }\end{array}$ & $\begin{array}{l}\text { Vorren et al. } \\
(2012)\end{array}$ \\
\hline 3 & $\begin{array}{l}\text { Northern } \\
\text { Europe, } \\
\text { regional }\end{array}$ & $\begin{array}{l}\text { Mul- } \\
\text { tiple }\end{array}$ & N Europe & $57-70$ & $8-35$ & - & Lake & Pollen & - & $\begin{array}{l}\text { Stacked summary pollen-based } \\
\text { temperature variability record } \\
\text { from } 36 \text { sites. Provides overall } \\
\text { terrestrial climate and vegeta- } \\
\text { tion response across N Europe }\end{array}$ & $\begin{array}{l}\text { Seppä et al. } \\
(2009)\end{array}$ \\
\hline 4 & $\begin{array}{l}\text { Langfjord- } \\
\text { jøkelen }\end{array}$ & Jøp-II2 & N Norway & 70.1 & 21.42 & 156 & Lake & $\begin{array}{l}\text { Titanium, } \\
\text { counts per } \\
\text { second }\end{array}$ & $<10$ & $\begin{array}{l}\text { Tracks glacial dynamics in the } \\
\text { coastal region of Northern } \\
\text { Norway }\end{array}$ & $\begin{array}{l}\text { Wittmeier } \\
\text { et al. (2015) }\end{array}$ \\
\hline 5 & Jervtjern & JRT & N Norway & 68.4 & 19.5 & 548 & Lake & $\begin{array}{l}\text { Pollen and } \\
\text { modeling }\end{array}$ & 67 & $\begin{array}{l}\text { Relative changes in the upper } \\
\text { altitudinal limit of the pine } \\
\text { forest, mapped against current } \\
\text { levels }\end{array}$ & $\begin{array}{l}\text { Sjögren et al. } \\
(2015) \text { and } \\
\text { Jensen and } \\
\text { Vorren (2008) }\end{array}$ \\
\hline 6 & $\begin{array}{l}N \text { Fen- } \\
\text { noscandia, } \\
\text { regional }\end{array}$ & Mul- & N Norway & $68-70$ & $20-30$ & - & Lake & Pollen & - & $\begin{array}{l}\text { Compilation of } 59 \text { pollen cores } \\
\text { across } N \text { Fennoscandia, track- } \\
\text { ing vegetation changes across } \\
\text { inland-coast, east-west axes }\end{array}$ & $\begin{array}{l}\text { Sjögren and } \\
\text { Damm (2019) } \\
\text { and Damm } \\
\text { et al. (2019) }\end{array}$ \\
\hline 7 & $\begin{array}{l}\text { Barents } \\
\text { Sea }\end{array}$ & $\begin{array}{l}\text { PL-96- } \\
112 \\
\text { BC }\end{array}$ & $\begin{array}{l}\text { Barents } \\
\text { Sea }\end{array}$ & 71.74 & 42.61 & -286 & Marine & Dinocysts & 149 & $\begin{array}{l}\text { Combined measures of marine } \\
\text { bioproductivity and sea-ice } \\
\text { dynamics in the Barents Sea }\end{array}$ & $\begin{array}{l}\text { Voronina et al. } \\
(200 I) \text { and De } \\
\text { Vernal et al. } \\
(2013)\end{array}$ \\
\hline
\end{tabular}

Note that for proxy I: Moving average smoothing (50 years) was applied to raw data of annual resolution for visualization purposes. Magnitude of temperature variation is therefore less substantial. Please consult original data for realistic annual temperature reconstructions.

Table 4. Identified tephras and other proxies of volcanic impacts in Northern Norway.

\begin{tabular}{|c|c|c|c|c|c|c|}
\hline Site & Site type & Sample no. & $\begin{array}{l}\text { Associated peat } \\
\text { median age, cal } \\
\text { BP (1950) }\end{array}$ & Volcanic source & $\begin{array}{l}\text { Known age of } \\
\text { identified event, } \\
\text { cal BP (1950) }\end{array}$ & Reference \\
\hline Tønsnes & $\begin{array}{l}\text { Bog near } \\
\text { archeological site }\end{array}$ & ТØ---12---В 358 & 6900 & Lairg-A & 6900 & $\begin{array}{l}\text { Balascio and Ander- } \\
\text { son }(2016)\end{array}$ \\
\hline Borge & Peatland & - & 6900 & Lairg-A & 6900 & Pilcher et al. (2005) \\
\hline Sellevollmyra & Peatland & SEL-10 & 6735 & Lairg-A & 6900 & Vorren et al. (2007) \\
\hline Borge & Peatland & $\begin{array}{l}\text { QUB-60I/GI: Borge } \\
\text { unknown } 22\end{array}$ & 6650 & - & - & Pilcher et al. (2005) \\
\hline Borge & Peatland & $\begin{array}{l}\text { QUB-601/G2: Borge } \\
\text { unknown } 23\end{array}$ & 6650 & - & - & Pilcher et al. (2005) \\
\hline Borge & Peatland & $\begin{array}{l}\text { QUB-600/G I: Borge } \\
\text { unknown } 20\end{array}$ & 6370 & - & - & Pilcher et al. (2005) \\
\hline Borge & Peatland & $\begin{array}{l}\text { QUB-600/G2: Borge } \\
\text { unknown } 21\end{array}$ & 6370 & - & - & Pilcher et al. (2005) \\
\hline Borge & Peatland & $\begin{array}{l}\text { QUB-598/GI: Borge } \\
\text { unknown } 16\end{array}$ & 5800 & - & - & Pilcher et al. (2005) \\
\hline Borge & Peatland & $\begin{array}{l}\text { QUB-598/G3: Borge } \\
\text { unknown } 17\end{array}$ & 5800 & - & - & Pilcher et al. (2005) \\
\hline Borge & Peatland & $\begin{array}{l}\text { QUB-598/G5: Borge } \\
\text { unknown } 18\end{array}$ & 5800 & - & - & Pilcher et al. (2005) \\
\hline Sellevollmyra & Peatland & SEL-9 & 5771 & - & - & Vorren et al. (2007) \\
\hline Sellevollmyra & Peatland & SEL-8 & 5667 & - & - & Vorren et al. (2007) \\
\hline $\begin{array}{l}\text { Lapland } \\
\text { dendro }\end{array}$ & $\begin{array}{l}\text { Dendrochronol- } \\
\text { ogy }\end{array}$ & - & 4800 & - & 4800 & $\begin{array}{l}\text { Helama et al. } \\
(2013)\end{array}$ \\
\hline Sellevollmyra & Peatland & SEL-7 & 4662 & - & - & Vorren et al. (2007) \\
\hline $\begin{array}{l}\text { Lapland } \\
\text { dendro }\end{array}$ & $\begin{array}{l}\text { Dendrochronol- } \\
\text { ogy }\end{array}$ & - & 4514 & - & 4514 & $\begin{array}{l}\text { Helama et al. } \\
(2013)\end{array}$ \\
\hline Bødalsvatnet & Lake & Lower sample & 4287 & Hekla-4 & 4260 & Pilcher et al. (2005) \\
\hline Borge & Peatland & - & 4287 & Hekla-4 & 4260 & Pilcher et al. (2005) \\
\hline Tønsnes & $\begin{array}{l}\text { Bog near archeo- } \\
\text { logical site }\end{array}$ & ТØ---12---В 230 & 4260 & Hekla-4 & 4260 & $\begin{array}{l}\text { Balascio and Ander- } \\
\text { son }(2016)\end{array}$ \\
\hline Sellevollmyra & Peatland & SEL-6 & 4120 & Hekla-4 & 4260 & Vorren et al. (2007) \\
\hline Sellevollmyra & Peatland & SEL-5 & 3821 & Kebister? & 3750 & Vorren et al. (2007) \\
\hline
\end{tabular}


Table 4. (Continued)

\begin{tabular}{|c|c|c|c|c|c|c|}
\hline Site & Site type & Sample no. & $\begin{array}{l}\text { Associated peat } \\
\text { median age, cal } \\
\text { BP (1950) }\end{array}$ & Volcanic source & $\begin{array}{l}\text { Known age of } \\
\text { identified event, } \\
\text { cal BP (1950) }\end{array}$ & Reference \\
\hline $\begin{array}{l}\text { Lapland } \\
\text { dendro }\end{array}$ & $\begin{array}{l}\text { Dendrochronol- } \\
\text { ogy }\end{array}$ & - & 3534 & Thera? & 3534 & $\begin{array}{l}\text { Helama et al. } \\
(2013)\end{array}$ \\
\hline $\begin{array}{l}\text { Lapland } \\
\text { dendro }\end{array}$ & $\begin{array}{l}\text { Dendrochronol- } \\
\text { ogy }\end{array}$ & - & 3529 & Thera? & 3529 & $\begin{array}{l}\text { Helama et al. } \\
(2013)\end{array}$ \\
\hline $\begin{array}{l}\text { Lapland } \\
\text { dendro }\end{array}$ & $\begin{array}{l}\text { Dendrochronol- } \\
\text { ogy }\end{array}$ & - & 3414 & Thera? & 3414 & $\begin{array}{l}\text { Helama et al. } \\
(2013)\end{array}$ \\
\hline $\begin{array}{l}\text { Lapland } \\
\text { dendro }\end{array}$ & $\begin{array}{l}\text { Dendrochronol- } \\
\text { ogy }\end{array}$ & - & 3403 & Thera? & 3403 & $\begin{array}{l}\text { Helama et al. } \\
(2013)\end{array}$ \\
\hline Sellevollmyra & Peatland & SEL-4 & 3123 & Hekla-3 & 3000 & Vorren et al. (2007) \\
\hline $\begin{array}{l}\text { Lapland } \\
\text { dendro }\end{array}$ & $\begin{array}{l}\text { Dendrochronol- } \\
\text { ogy }\end{array}$ & - & 2824 & - & 2824 & $\begin{array}{l}\text { Helama et al. } \\
(2013)\end{array}$ \\
\hline $\begin{array}{l}\text { Lapland } \\
\text { dendro }\end{array}$ & $\begin{array}{l}\text { Dendrochronol- } \\
\text { ogy }\end{array}$ & - & 2280 & - & 2280 & $\begin{array}{l}\text { Helama et al. } \\
(2013)\end{array}$ \\
\hline Borge & Peatland & $\begin{array}{l}\text { QUB-565/G2: Borge } \\
\text { unknown I5 }\end{array}$ & 2250 & - & - & Pilcher et al. (2005) \\
\hline Borge & Peatland & $\begin{array}{l}\text { QUB-567/GI: Borge } \\
\text { unknown I2 }\end{array}$ & 1500 & - & - & Pilcher et al. (2005) \\
\hline Borge & Peatland & $\begin{array}{l}\text { QUB-567/G2: Borge } \\
\text { unknown I3 }\end{array}$ & 1500 & - & - & Pilcher et al. (2005) \\
\hline $\begin{array}{l}\text { Lapland } \\
\text { dendro }\end{array}$ & $\begin{array}{l}\text { Dendrochronol- } \\
\text { ogy }\end{array}$ & - & 1414 & - & 1414 & $\begin{array}{l}\text { Helama et al. } \\
(2013)\end{array}$ \\
\hline $\begin{array}{l}\text { Lapland } \\
\text { dendro }\end{array}$ & $\begin{array}{l}\text { Dendrochronol- } \\
\text { ogy }\end{array}$ & - & 1408 & - & 1408 & $\begin{array}{l}\text { Helama et al. } \\
(2013)\end{array}$ \\
\hline Sellevollmyra & Peatland & SEL-3 & 1194 & Mixed, 'AD 860’? & - & Vorren et al. (2007) \\
\hline Indrepollen & Lake & $N / A$ & $\mathrm{~N} / \mathrm{A}$ & $\begin{array}{l}\text { AD 860, Tjornuvik } \\
\text { B }\end{array}$ & 1060 & Pilcher et al. (2005) \\
\hline Sellevollmyra & Peatland & SEL-2 & 804 & Hekla-I & 846 & Vorren et al. (2007) \\
\hline Sellevollmyra & Peatland & SEL-I & 766 & Hekla-II58? & 792 & Vorren et al. (2007) \\
\hline Sellevollmyra & Peatland & SEL-0 & 680 & Öræfajökull-1 362? & 588 & Vorren et al. (2007) \\
\hline Bødalsvatnet & Lake & Upper sample & N/A & Öræfajökull-| 362? & 588 & Pilcher et al. (2005) \\
\hline
\end{tabular}

Credits: Balascio and Anderson (2016); Helama et al. (2013); Pilcher et al. (2005); Vorren et al. (2007).

Shard concentrations and geochemical composition are not reported here as they are not consistently reported in original reports. Please consult references.

particularly rich in high-resolution paleoenvironmental records, derived from a wide variety of proxy types.

Data were collected from the Arctic Holocene Proxy Climate Database (Sundqvist et al., 2014) and the NOAA (National Oceanographic Data Center) data repository, as well as by the courtesy of original authors (Sjögren et al., 2015). The selection of paleoenvironmental reconstructions was based on criteria of ecological relevance, data quality and resolution, as well as geographic distribution and coverage of proxy types. The geographic location of the paleoenvironmental records is given in Figure 4.

\section{The mid- and late-Holocene tephrochronology of Arctic Norway}

A further line of inquiry concerning the Gressbakken termination is the potential for long-range effects of distant eruptions. Such impacts have demonstrably led to pronounced climatic perturbations in the higher latitudes of Fennoscandia, with marked societal consequences on multiple occasions (Büntgen et al., 2016; Helama et al., 2013, 2018; Holopainen and Helama, 2009; Huhtamaa and Helama, 2017; Löwenborg, 2012; Sigl et al., 2015; Tvauri, 2014). Previously, a tephrochronological lattice has been assembled for the western coast of Northern Norway (Pilcher et al., 2005), although no attempts have ever been made at correlating these with the archeological record.

Attempts to investigate past human impacts of volcanically induced climate perturbation demand fairly high resolution of both the environmental and archeological/historical archives. With regard to Northern Fennoscandia, the existence of an annually resolved dendrochronology successfully correlated with volcanic Sulfur signatures in Greenland ice-cores (Helama et al.,
2013) provides ideal conditions for such an investigation, especially as it can be matched with an extensive and well-curated archeological record. Numerous tephra occurrences are known from Northern Norway (Table 4). Several of the tephra layers have been geochemically related to known, mostly Icelandic, eruptions and some (e.g. the $6900 \mathrm{cal}$ BP Lairg-A and $4200 \mathrm{cal}$ BP Hekla- 4 events) have been identified across multiple sites, and across Sweden (Watson et al., 2016). These tephras represent a robust fraction of Holocene volcanic activity in Iceland (cf. Lawson et al., 2012; Swindles et al., 2011; Watson et al., 2017).

The climatic, environmental, or societal impacts of the specific events depositing tephra in Northern Fennoscandia are not known. Considering the comparatively moderate magnitude (Volcanic Explosivity Index $\leqslant 5$ ) of most Icelandic eruptions (Larsen et al., 2001), the expected impact was most likely correspondingly moderate, if any. Yet, the socio-ecological effects of eruptive events, including effects at long range, are not always linearly correlated with eruptive magnitude (Riede, 2019; Sheets, 2012; Torrence, 2019; Zeidler, 2016). It is the indirect, climatic effects we would expect to mostly influence Northern Fennoscandia (e.g. Jenkins et al., 2015; Wilson et al., 2015). Especially in light of recent work considering the climatic forcing of Northern Hemisphere climate and its downstream effects on human societies in the Holocene, we here consider the dates of known eruptions in parallel with selected paleoenvironmental records and the Gressbakken phase evidence.

\section{Results}

Plotting the known eruptive impacts in Northern Norway (red crosses) against the stacked paleoenvironmental proxies and 

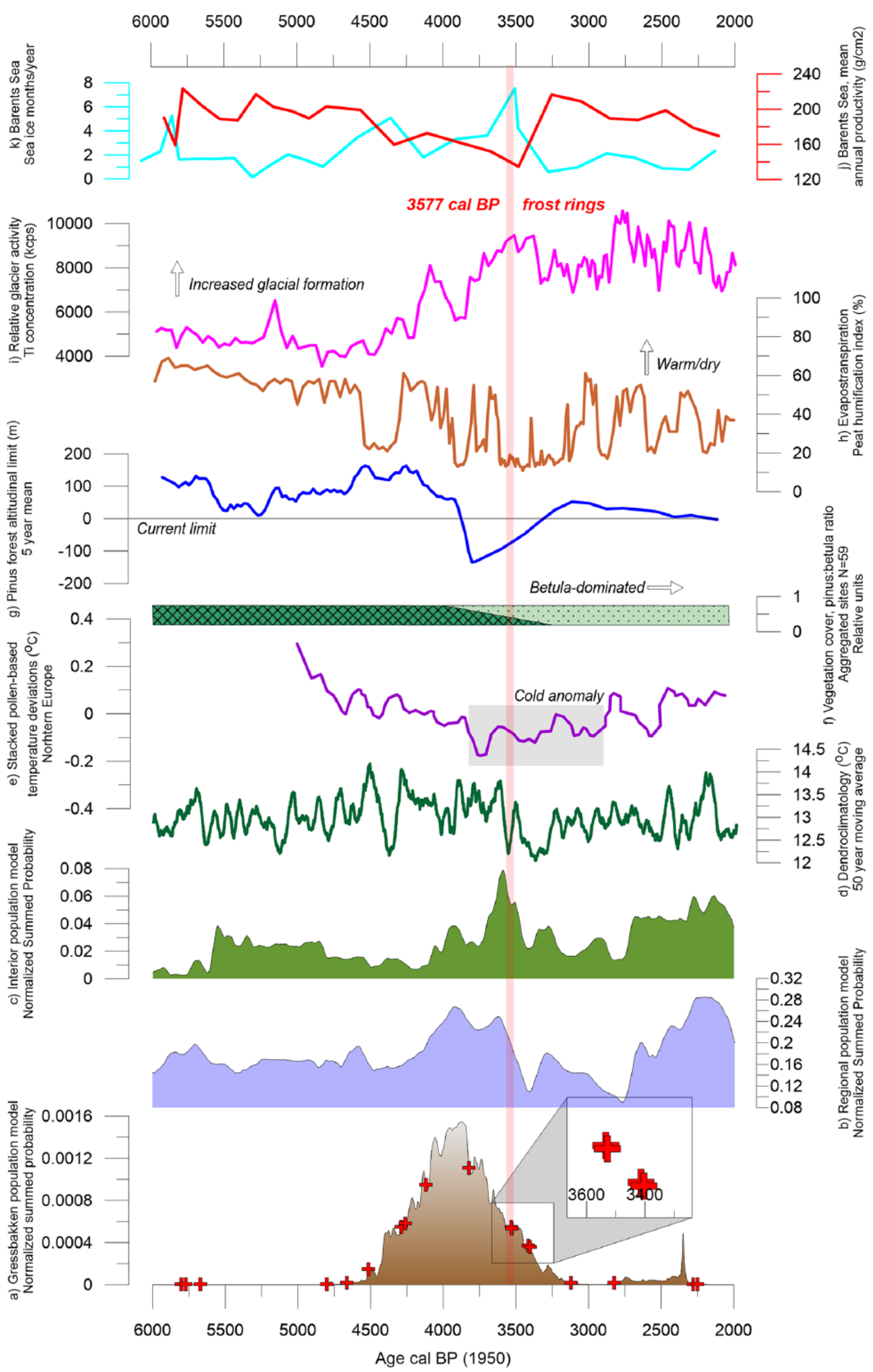

Figure 5. Stacked plots of population models and paleoenvironmental reconstructions. (a) Gressbakken population model, normalized summed probability. (b) Regional population model, normalized summed probability. (c) Interior population model, normalized summed probability. (d) Dendroclimatology $\left({ }^{\circ} \mathrm{C}\right), 50$-year moving average. (e) Stacked pollen-based temperature deviations $\left({ }^{\circ} \mathrm{C}\right)$, Northern Europe. $(\mathrm{f})$ Vegetation cover, pinus-betula ratio; aggregated sites $N=59$; relative units. (g) Pinus forest altitudinal limit ( $\mathrm{m}$ ), 5-year mean.

(h) Evapotranspiration, peat humification index (\%). (i) Relative glacier activity,Ti concentration (kcps). (j) Barents Sea, mean annual productivity $\left(\mathrm{g} / \mathrm{cm}^{2}\right)$. $(\mathrm{k})$ Barents Sea, sea ice months/year.

Red crosses at the bottom mark tephra occurrences as listed in Table 4 plotted against settlement intensity proxy of dated Gressbakken houses. Magnifier marks the eruptive cluster associated with the Thera eruptions with assumed direct implications for the human ecodynamics in the study area. Red vertical line marks the 3577 cal BP frost ring-producing event. See Table 3 for information on climate data. Plot (e) redrawn and adapted from Seppä et al. (2009: 53I). Plot (f) redrawn and adapted from Damm et al. (2019:5), data in Sjögren and Damm (2019). 
palaeodemographic models shown in Figure 5 does not yield any consistent pattern. The Icelandic eruptions identified in Norway are of relatively minor magnitude, and it is not possible to ascribe any discernable effect to them. The Thera events are a different matter, as their ecological impact has been directly recorded in the local dendrochronology (Helama et al., 2013). Of particular interest is the cluster of four eruptive events that occurred within a 131-year time window at 3534, 3529, 3414, and $3403 \mathrm{cal} \mathrm{BP}$, coinciding with the Gressbakken termination (Figure 5 - magnifier). At minimum, one of these is likely ascribable to the well-known yet contentiously dated Thera eruption (e.g. Friedrich et al., 2006; Pearson et al., 2018). One of very few frost rings identified throughout prehistoric Northern Europe has been identified and securely dated to $3577 \mathrm{cal}$ BP in the local dendrochronology (Helama et al., 2019) - plotted as a vertical red bar in Figure 5. Such disrupted growth rings result from freezing temperatures during the growing season, in this case inferred for July and attributed to the effects of a dust veil following the Thera eruption. Furthermore, a number of eruptive events have been shown to occur within the mid-fourth millennium cal BP, suggesting that the Gressbakken termination occurred at a time of relatively frequent, large-scale eruptive events: North-American and Asian tephras have been identified in Northern Europe (Plunkett and Pilcher, 2018), several of which coincide closely with the Gressbakken termination, as well as Icelandic LBA-2 tephra has been identified in central Sweden, dated to 3550-3650 cal BP (Wastegård et al., 2009). Most notable among these is the massive eruption of Aniakchak (Alaska, USA) dated to $3590 \mathrm{cal} \mathrm{BP,} \mathrm{which}$ itself had considerable effects on Arctic ecosystems and contemporaneous forager groups in Alaska (Riede et al., 2017; Tremayne and Winterhalder, 2017; VanderHoek and Nelson, 2007). Analogous to the 6th-century $\mathrm{AD}$, these successive eruptive events appear to have had a marked and prolonged cooling effect in Northern Fennoscandia, clearly reflected in the Finnish Lapland dendrochronology (Helama et al., 2013).

The paleoenvironmental data show that prior to the mid-tolate-Holocene transition ( 4200 cal BP), climate conditions seem to have been uniformly quite stable and productive. This can be seen as the remnants of the Holocene Thermal Maximum providing reduced precipitation and higher temperatures $(1 \pm$ $0.5^{\circ} \mathrm{C}$ above modern conditions). The subsequent period (40003500 cal BP) was wetter and more unstable with temperatures closer to present-day conditions $\left( \pm 0.5^{\circ} \mathrm{C}\right)$, and a major reconfiguration of the local climate system transpired by the end of the period (Sjögren and Damm, 2019: 8). A major climate alteration took place between $3800-3000$ cal BP, and was highly significant in terms of cementing the unstable, moist, and cooler conditions of the late-Holocene - identified in the stacked temperature deviations from across Northern Europe (Figure 5e; Seppä et al., 2009: 531). The transition marks the beginning of the neo-glaciation, witnessed locally by the reformation of the Lenangen glaciers (Lyngen, northern Troms) due to a major increase in winter precipitation (Bakke et al., 2005: 536). The included proxy on glacial dynamics (Figure 5i) demonstrates that the Gressbakken phase started alongside the re-advance of local glaciers (both in northern Troms and western Finnmark Counties) which had all but disappeared during the Holocene Thermal Maximum. The Gressbakken settlement intensity proxy continues to increase and reaches its apex during a marked glacial retreat. The regress of the Gressbakken settlement proxy from $\sim 3700$ cal BP corresponds to the most dramatic glacial increase throughout the mid-to-late-Holocene period, specifically between 3700 and 3400 cal BP.

This had major implications for vegetation cover in Northern Norway, as the tree-line retreated markedly into lower altitude and latitude. The incipient decline of the Gressbakken intensity proxy (Figure 5a) corresponds to a major drop in Pinus altitudinal limit of $\sim 300 \mathrm{~m}$ and reduced latitudinal distribution with a shift toward Bet$u l a$ as the dominant forest species, demonstrated by Figure $5 \mathrm{f}$ and $\mathrm{g}$.
What is more, the reduced activity suggested by both the regional and interior models corresponds well with the prolonged cold anomaly 3800-3000 in Figure 5e. Pollen data (sites, $N=59$ ) from the entire Finnmark region indicate a marked shift in the birch/pine ratio around $3600 \mathrm{cal} \mathrm{BP}$ in favor of birch, plotted in Figure 5f (Sjögren and Damm, 2019: 8). This is a vegetation response to wetter and/or colder climate, and corresponds directly to the peat humification index (Figure 5h). Significantly, the highest percentage of peat moss (Sphagnum) growth throughout the entire Holocene occurred 3600 3500 cal BP (Vorren et al., 2012: 23), which is a response to cold and moist conditions. This is also consistent with the dendrochronological data demonstrating an extreme cold spell centered on $3550 \mathrm{cal}$ BP (Figure 5d; Grudd et al., 2002; Helama et al., 2013).

A general cooling trend throughout the Gressbakken phase, and particularly cold and adverse conditions around the termination are indicated by the marine proxies documenting plummeting productivity and peaking sea-ice concentrations closer to the eastern coast (Figure $5 \mathrm{j}$ and $\mathrm{k}$ ).

When considering the first rigorous dating scheme for the Gressbakken phase (Figure 5a) and its climatic and cultural setting, we suggest $3500 \mathrm{cal} \mathrm{BP}$ as the end date for the Gressbakken phase. This is somewhat out of line with previous attempts at defining its temporal extent, and we therefore suggest that the Younger Stone Age/Early Metal Period transition might be pushed forward by about 300 years to $3500 \mathrm{cal} \mathrm{BP}$ and thereby aligning it more directly with the general Neolithic/Bronze Age transition in Northern Europe. The small increase in the Gressbakken activity proxy centered on $2500 \mathrm{cal}$ BP is likely to be secondary reuse of Gressbakken houses by people pursuing a more mobile post-Gressbakken adaptation, a practice that is becoming ever more visible through increased dating efforts (Damm et al., 2019; Skandfer, 2012). The recognition that the classic Gressbakken houses might only have been one functional component of a larger settlement pattern including various other forms of habitations structures (Niemi and Oppvang, 2018: 79) does not undermine the dating results presented here. The activity intensity at other typologically separate habitation sites follows the same pattern, and thus corroborates the results of our dating scheme.

When compared to the regional population model (Figure 5b), it is clear that the Gressbakken occupation intensity proxy is the single most important contributor to the 4000 cal BP population peak. The implication is that the population dynamic of the Gressbakken phase is to a large extent the main driver of the total regional population fluctuations at the time. However, the regional population proxy keeps growing after the intersection with the collapsing Gressbakken proxy. This is explained by increased inland exploitation, with a marked peak at about 3600 cal BP (Figure 5c). Despite the low number of interior dates, the results are in strong accordance with the expectation of increased residential mobility and economic diversification as risk management responses during times of stress.

The result of reviewing the settlement data is an apparent hiatus in settlement activity following the Gressbakken termination (see Helskog, 1984: 47). Lower-elevation beach ridge sites in Varanger previously used to argue for post-Gressbakken continuous habitation, such as at the Veidneset and Angsnes peninsula (Hood, 2019b: 33) and at Mortensnes (Johansen and Odner, 1968; Schanche, 1988), show a hiatus of 2-4 m of vertical shoreline displacement following the Gressbakken phase before habitation structures reappear. The hiatus is further corroborated by investigations at the Nyelv site, in which major activity corresponds to the height of the Gressbakken phase (4000 cal BP), while documented activity ceases $\sim 3650$ cal BP along with a trend toward reduced indicators of settlement intensity (Niemi and Oppvang, 2018: 73). What is more, the recent investigation and dense dating of the houses at the Abelsborg site further substantiate this occupation hiatus, as all major activity seems to end along with the 
Gressbakken phase (Oppvang, 2018). Critical factors such as the impact of later reuse and potential taphonomic biases in the preservation of lower elevation houses being more exposed to modern settlement should be kept in mind. Nonetheless, the pattern identified here seems to be consistent across multiple sites of different preservative states.

Outside Varanger, results from multiple and extensive excavations in western Finnmark contribute to the picture of large-scale changes, in line with the indices of the Gressbakken collapse. The multi-period sites of Slettnes, Melkøya, Skjærvika, and Fjellvika all testify to a drastic change in settlement type with the termination of the Gressbakken phase, involving a strong reduction of pit houses in favor of open-air sites. During the interval of the Gressbakken phase, large pit houses with marked entrances and the occasional preservation of rectangular stone-lined hearths occur in western Finnmark. Yet also here, they disappear during $~ 3600 / 3500$ cal BP (e.g. Sundfjæra S11 (Hesjedal et al., 2009: 305), Slettnes F82 (Hesjedal et al., 1996: 124), and Skjærvika S27 (Henriksen and Valen, 2013: 276)). The processes characterizing the terminal Gressbakken phase in Finnmark appear to have had repercussions also for the inhabitants of present-day Troms, and possibly Nordland County as well. This is indicated by major shifts in economy and settlement patterns there (Arntzen, 2015; Blankholm, 2011).

As a consequence, recent accumulation of data underline rather than contradict the widespread impact of the Gressbakken termination - and go on to suggest a hiatus in occupation at multiple sites in the core area of the phenomenon. Significantly, the suggested termination of the Gressbakken phase (3500 cal BP) corresponds to one of the most pronounced cold periods in the entire Holocene, only surpassed by the 'Little Ice Age' and the 8.2-ka event, dated to 3800-3000 cal BP from a local multi-proxy reconstruction (Seppä et al., 2009: 531). This cold period marks a regime shift from the warmer, drier conditions of the Holocene Thermal Maximum to colder and wetter conditions in the late Holocene. The evidence therefore points in the direction of direct climate forcing of human demographic decline. This large-scale correlation is further explored below in terms of its possible middle-range causal mechanics.

\section{Discussion}

Hunter-gatherer societies have multiple risk management strategies at their disposal (Halstead and O'Shea, 1989; Minc and Smith, 1989). Most commonly, a combination of strategies would be applied in most crisis situations, although technological limits would act on, for example, the ability to store food, while ecological constraints limit the degrees to which resource-use can be intensified or additional resources be added to the repertoire. In the transition from Gressbakken to post-Gressbakken, we find a set of response mechanisms in accordance with the predictions stated initially, such as the break-up of semi-sedentary coastal settlements, as well as a significantly more dispersed occurrence of sites and the end of midden accumulation all testifying to increased mobility (Table 5).

Based on the environmental setting of the initial Gressbakken phase, the development of the substantial houses during this time may tentatively be explained as an adaptation to a climatic shift during a time of particulate cold and moist climate, resulting in increased winter storminess and heavy snowfall (Björckl and Clemmensen, 2004; Vorren et al., 2007: 272). Populations in Finnmark may have responded by aggregating in larger numbers during winter and by constructing sturdier dwellings. This is inferred from house morphology and is to some extent backed by faunal seasonal reconstructions indicating potential year-around use, with a focus on particular dense winter-spring habitation related to cod exploitation, which spawns on these coasts during winter (Olsen, 1967; Renouf, 1989, cf. Hodgetts, 2010).
Numerous paleoenvironmental records of Northern Norway strongly indicate, however, a downward spiral following the climate shift at $3800 \mathrm{cal} \mathrm{BP}$ as the onset of significantly colder temperatures and hence less productive environs, with drastic climate events centered on the period around $3600 \mathrm{cal} \mathrm{BP}$. In fact, one of the Holocene's lowest annual temperatures has been inferred for $3534 \mathrm{cal} \mathrm{BP}$ as the impact of the Santorini eruption, as part of a progressive cooling toward this chilly nadir (Helama et al., 2013: $4)$. The wetter and cooler conditions (the increased effective precipitation) following the 3800 cal BP climate shift raised the water table and resulted in widespread paludification (Sjögren and Damm, 2019: 12; Vorren et al., 2007: 272). Such conditions are highly reductive to pine growth, succession, and reproduction. The transition from mixed pine forest to a sparser vegetation dominated by birch is a general trend during late-Holocene Northern Fennoscandian, and a distinct reduction in Pinus has been demonstrated for the core Gressbakken area in eastern Finnmark (Hicks and Hyvärinen, 1997; Karlsson et al., 2007; Sjögren and Damm, 2019). If the advent of the Gressbakken phase was (partially) a response to the snowy winters by building large, sturdy, and wood-demanding structures, the rapidly retreating tree-line potentially made it more difficult to keep up the construction and maintenance of such resource-demanding houses. If so, it would be a predictable outcome if such house technology was abandoned in favor of less wood-demanding construction types. Despite the fact that Siberian drift wood was likely present regardless of vegetation cover in Varanger, rapid forest decline increased house maintenance costs through foraging and preparation time expenditures, as well as restraints on wood technology and fuel.

The climate shift and forest decline also had major impacts on biogeography. It has been suggested that the historic and current migratory behavior of large reindeer populations only formed along with the late-Holocene deforestation and that a sedentary (forest) ecotype variant of reindeer populated the coastal region of Northern Norway during the forest maximum (8300-4500 cal BP; Hood, 2019a: 23). As such, the Gressbakken termination would have been particularly driven by so-called 'rain-on-snow' events, forming a solid ice crust impenetrable to reindeer. Mass starvation can occur (Burch, 2012; Chernow, 1985; Spiess, 1979) and is known both historically and from contemporary accounts as a cause of reindeer population collapse (Forbes et al., 2016; Turunen et al., 2016; Tyler, 2010). In addition, deep snow increases predation by wolves and wolverines (Mattisson et al., 2016), and extended cold combined with deep snow is known to spike mortality among Cervidae, especially elk (Alces alces) (Kojola et al., 2006). Reindeer would therefore become less accessible on the coast throughout the Gressbakken phase. Note that to the maritime-adapted Gressbakken population, the reduced availability of reindeer most likely was less problematic in terms of reduced caloric return rates but rather created bottlenecks in non-food ungulate products. As suggested by ethnographic insights, reindeer products are critical for marine hunter-gatherers (Smith, 1991; Stenton, 1991b). The non-negotiable need for reindeer hides in particular has been stressed repeatedly, as they provide the only product meeting the thermal requirements of Arctic winter clothing in the study area. Arguably, reindeer played so important a role in the more quasi-sedentary, maritime adaptive strategy of the Gressbakken phase that the observable material culture change in favor of increased mobility and inland exploitation could be a response to reduced reindeer numbers or increased dispersion, either of which would have made the procurement of suitable hides more difficult and costly.

The archaeofaunal evidence from the Gressbakken phase supports the importance of reindeer products: Despite low absolute abundance, reindeer bones were a fundamental part of the technical requirement for the maritime adaptation, not just in terms of 
Table 5. Evidence for the application of key risk management strategies in the termination of the Gressbakken phase.

\begin{tabular}{|c|c|c|c|}
\hline \multirow{2}{*}{$\begin{array}{l}\text { General coping } \\
\text { strategies }\end{array}$} & \multicolumn{2}{|l|}{ Continuum of stress conditions } & \multirow[t]{2}{*}{ Gressbakken response evidence } \\
\hline & Low severity (localized/short-term) & High severity (regional/long-term) & \\
\hline Diversification & Local secondary resources & Extra-regional resources & Shift in adaptive strategy \\
\hline Mobility & $\begin{array}{l}\text { Increased intra-regional logistic/ } \\
\text { residential mobility }\end{array}$ & Inter-regional migration & $\begin{array}{l}\text { Settlement hiatus, increased residential mobility, } \\
\text { possible migration, end of midden accumulation }\end{array}$ \\
\hline Storage & Intra-community (physical) & Inter-community (social storage) & Regional population decline \\
\hline Exchange & $\begin{array}{l}\text { Generalized reciprocity and infor- } \\
\text { mal sharing at intra-societal level }\end{array}$ & $\begin{array}{l}\text { Delayed reciprocity and formalized } \\
\text { trade at inter-regional level or negative } \\
\text { reciprocity (raiding, theft) }\end{array}$ & $\begin{array}{l}\text { Lack of trade networks and complementary } \\
\text { adapted groups. Disintegration of inter-regional } \\
\text { Gressbakken complex }\end{array}$ \\
\hline
\end{tabular}

hides and sinews, but also as raw material for the production of fish hooks and harpoons (Hodgetts, 2000). The distribution of reindeer body elements indicates that reindeer were neither hunted nor slaughtered at the settlement sites. However, low meat/fat utility body elements were selected primarily on the basis of tool-making suitability and brought to habitation sites, and the very low proportion of split bones for marrow extraction at Gressbakken sites further highlights the non-dietary function of reindeer - used to argue that the population was under no dietary stress (Hodgetts, 2000). Regardless, any major restructuration of reindeer migration routes or demographic bottlenecks would have important implications for the human population at hand.

Concerning the impact of volcanism and related to the identified tephra-occurrences in Northern Norway, even light tephra fall could have aggravated the crisis initiated by the deteriorating climate. It has been demonstrated that tephra-laden vegetation can lead to severe dental abrasion in animals and humans, with the impact being particularly strong on grazing animals (Riede and Wheeler, 2009). In addition, very fine-grained volcanic ash can enter the airways and cause respiratory irritation alongside potential longer term effects due to the chemical loading of the particles (Horwell and Baxter, 2006; Horwell et al., 2015). A particularly interesting effect in the case of Northern Norway is the detrimental impact of the acidic ash fallout and acid rain on lichen and mosses which form the dietary basis of reindeer. This has been demonstrated to have had severe impact on comparable prehistoric hunter-gatherers in Alaska (Riede et al., 2017; VanderHoek and Nelson, 2007), where it led to the Alaska-wide population decline and disappearance of the Arctic Small Tool tradition following the 3600 cal BP Aniakchak eruption and an hypothesized caribou collapse (Tremayne and Brown, 2017). Note that direct, local ashfall is not a requirement for this to have an effect.

With a drop in net primary productivity (NPP) following reduced effective temperature (ET) and an increase in resource patchiness along with a potential destabilization of the existing bio-geographical regime, mobility needs to be adjusted toward the forager-end of the adaptive spectrum in order to minimize risk and uphold caloric return rates (Solich and Bradtmöller, 2017; Whallon, 2006). Increasing resource patchiness is expected to occur from $3800 \mathrm{cal} \mathrm{BP}$ as an initial consequence of deforestation. Given the existence and availability of highly productive and stable patches, the ideal free distribution predicts reduced residential mobility under such conditions of increasing patchiness (Bettinger and Grote, 2016). One might have expected an economic shift toward intensification of marine resources as a response mechanism to maintain return rates - which arguably was the case in Kodiak, Alaska, under similar conditions (Fitzhugh, 2003). However, this is contrary to what we find, as residential mobility seems to increase along with heightened resource patchiness of the terrestrial environment and increased interior exploitation (Figure 5a). This result is more in line with the economic response by Thule Inuit to reduced caribou densities on Baffin Island, Canada, suggesting an inland-oriented procurement strategy during periods of caribou population decline (Stenton, 1991a).

Despite the uncertainty of how the observed Late-Holocene cooling affected aquatic resources, the available marine productivity measures (Figure 5i) suggest an absolute low corresponding to the Gressbakken termination and the eruptions around this time. We therefore attribute the societal impacts as documented archeologically to a cross-ecotone productivity decline along with a lack of any densely packed and highly abundant marine resource able to compensate the reduction in terrestrial productivity, as well as the inherent need for noncaloric ungulate products. In all, this environmental setting would drive down the sustainable patch-specific foraging time, and result in both more frequent moves and shorter durations of stay - which is nicely mirrored in the occupation hiatus and settlement restructuration following the Gressbakken phase. Increased mobility has implications for life-history decisions, for birth-spacing and fertility, and hence for population density (MacDonald and Hewlett, 1999; Surovell, 2000). Downstream, lower temperatures are strongly correlated with reduced population densities (Binford, 2001; Tallavaara et al., 2015) although not necessarily in terms of packing in Arctic environments (for a convincing case of 'climate deteriorations' as a positive trend in the Arctic, see Desjardins (2013)).

Recent aDNA studies have demonstrated the influx and admixture of Siberian genetic material into the gene pool of adjacent areas in Finland and particularly Murmansk Oblast in Russia by 3500 cal BP (Lamnidis et al., 2018; Sarkissian et al., 2013). The sampled individuals from Bolshoy Oleni Ostrov were uncovered in graves containing multiple finds of asbestos-tempered textile/imitated textile ceramics and Lovozero ware (Murashkin et al., 2016). This ceramic type has a distinct eastern distribution and new, direct dating efforts suggest that it was introduced to Northern Norway at the time of the Gressbakken termination (Hop, 2016; Lavento, 2001; Oppvang, 2009; Pääkkönen et al., 2018; Seitsonen et al., 2012). The influx of eastern genetic and archeological material corresponding to the major demographic and economic shift in Northern Norway is intriguing and potentially indicative of more extensive population movements, albeit beyond our ability to demonstrate empirically at this point. Given an absolute population decline, along with a shift in economy and settlement pattern, the Gressbakken collapse may have further facilitated a successful in-migration from the southeast - thus corresponding to ecological source/sink dynamics (Lamb et al., 2017; Robertson and Hutto, 2006).

As a final complication to the Gressbakken system, there is currently no reliable evidence of networks that might help mitigate rapid and high-impact climate change. This suggests that the reliance on complementary adaptations in which social networks are maintained to be activated during times of environmental stress as documented, for instance, in the Canadian Arctic by Minc and Smith (1989), would be difficult to implement 
(Tremayne and Winterhalder, 2017). A scenario in which coastal populations in Northern Norway interact with interior groups presupposes the existence of separate populations with specialized economies for such a risk reduction mechanism to have any effect. Although repeatedly promoted (e.g. Olsen, 1994: 76, 84), such claims are empirically unsubstantiated and have not become any less so with the accumulation of recent, large-scale interior surveys (Skandfer et al., 2019). The seeming lack of such safety nets among a near-sedentary coastal population is hypothesized to have reduced resilience and required other risk-reduction responses during times of crises. The indication of increased residential mobility is therefore highly consistent with expectations derived from foraging models (Bettinger and Grote, 2016; Halstead and O'Shea, 1989; Kelly, 1983; Lupo, 2007; Metcalfe and Barlow, 1992; Venkataraman et al., 2017).

Concerning networks as a fallback strategy, a predictable outcome of increasing population numbers and packing, such as witnessed at Gressbakken coastal sites (cf. Figure 5a), is a more self-sustained mating network with less incentive to introduce external genetic input. If so, population growth during, but potentially also some time prior to the Gressbakken phase, might have been an important driver of regionalism. We propose that regionalism of the Gressbakken phase made the population more susceptible to environmental change, as reduced network fluidity following increased sedentism weakens the important safetyvalve that networks demonstrably provide to hunter-gatherer populations globally (Binford, 2001; Kelly, 2013). Reliable proxies for negative reciprocity (Table 4) such as territoriality, inequality, and conflict is remarkably absent throughout the archeological record of Stone Age Northern Norway - also when compared to the apparent evidence from adjacent Northern Finland and to some extent Sweden - such as large defensive structures (Tallavaara and Pesonen, 2018), trends of increased territoriality/ regionalism, large pit house construction and technological dissemination (Forsberg, 2012; Holmblad, 2010; Mökkönen, 2011: 57), and even alleged social stratification (Vaneeckhout, 2010: 12). Either way, exclusive home ranges are a common outcome of increased locational investments (Binford, 1990; Borrero and Barberena, 2006; Cashdan et al., 1983; Smith and McNees, 1999). This minimal form of territoriality might therefore be a reasonable expectation of the Gressbakken phase as well, given population packing and near-sedentism. As it is, we propose that the increased sedentism and regionalism of the Gressbakken phase, combined with failing adaptive responses, resulted in reduced resilience in the face of rapid environmental change (Sheets, 1999, 2001, 2012). The results testify to a convergent catastrophe scenario, with the $\sim 3550$ cal BP eruptions providing the final stressor in a series of hardships that finally exceeded the adaptive mitigation capabilities/responses of the North Norwegian population. As such, these findings may suggest that the Gressbakken collapse is the northernmost demonstration of social and demographic upheavals contemporaneous with the European Bronze Age disturbance, as mapped by Risch and Meller (2015).

\section{Conclusion}

Based on a review of paleoenvironmental, tephrochronological, archeological data and palaeodemographic modeling, we argue that the termination of the North Norwegian Gressbakken phase of collector-like hunter-gatherers corresponds to - and was likely caused by - major changes in the biophysical environment. We show that the Gressbakken phase came to an end as a result of the cumulative effect of multiple stressors restricting the response options of this population (Dyer, 2002: 164; Riede et al., 2017). We believe this created a scenario of decline in line with what has been termed 'convergent catastrophes' (Moseley, 2002: 203).
We propose a chain of causal factors where a terrestrial ecosystem restructuring following the 3800 cal BP climate shift affected human communities through reduced terrestrial biomass and sparser wood coverage, resulting in lowered ungulate densities. These trends were further aggravated by multiple volcanic events around $3550 \mathrm{cal} \mathrm{BP}$, leading to substantive temperature declines at annual-to-decadal scales in local paleoenvironmental proxies and mapped through a compilation of tephra occurrences, also evidenced by the 3577 cal BP dendrochronological frost rings. These changes drove increased logistic/residential mobility in order to acquire the necessary reindeer products, which in turn necessitate demographic and technological adjustments. As predicted by human ecodynamic research, population numbers are highly dependent on temperature and primary productivity (Tallavaara et al., 2018), and the ethnographic record shows a negative impact of residential mobility on reproductive fitness (Hamilton et al., 2016; Kelly, 2013; Page et al., 2016). It is therefore likely that the Gressbakken population downturn evidenced across the regional and environ-specific palaeodemographic models presented here, actually entailed some element of absolute population decline. Significantly, the review of risk-mitigation strategies available to the Gressbakken population suggests some real adaptive limitations. The near-sedentism and higher locational investments seem to have resulted in reduced resilience in the face of rapid biophysical changes. Combined with the lack of complementary adapted inland populations for network mitigation of environmental risks, we suggest that the termination of the Gressbakken phase was an adaptive response to multi-layered ecodynamic forcing.

\section{Acknowledgements}

EKJ would like to express a sincere gratitude to professor Charlotte Damm (UiT) for helpful responses and proof-reading, and professor Bryan Hood (UiT) for introducing him to the topics at hand and for the selfless sharing of data, ideas, and time. The authors would also like to thank to the two anonymous reviewers of this paper who provided highly constructive and helpful feedback greatly improving our paper.

\section{Funding}

The author(s) disclosed receipt of the following financial support for the research, authorship, and/or publication of this article: This work was supported by the 'Stone Age Demographics' project funded by the Research Council of Norway (Grant No. 261760) and through a doctoral fellowship funded by UiT-The Arctic University of Norway. Additional financial support was provided by the Aarhus University Research Foundation (AUFF) in the form of a visiting $\mathrm{PhD}$ student grant. This allowed an extended stay at Aarhus University, facilitating the cooperation needed to produce the current research.

\section{ORCID iD}

Erlend Kirkeng Jørgensen (iD https://orcid.org/0000-0002-8573 $-4489$

\section{Supplementary material}

All data presented in this paper is attached as an appendix (Excel spreadsheet).

\section{References}

Allen JRM, Long AJ, Ottley CJ et al. (2007) Holocene climate variability in northernmost Europe. Quaternary Science Reviews 26(9): 1432-1453.

Andreassen RL (1985) Yngre steinalder på Sørøy. Økonomi og samfunn 4000-1000 f.Kr. Mag. Art. Tromsø: University of Tromsø, Institute of Social Science, Department of Archaeology. 
Angelbeck B (2016) The balance of autonomy and alliance in anarchic societies: The organization of defences in the Coast Salish past. World Archaeology 48(1): 51-69.

Arntzen JE (2015) Sandvika in northern Norway: The northernmost 'bronze age' settlement in Scandinavia. Fennoscandia Archaeologica 32: 3-34.

Bakke J, Dahl SO, Paasche Ø et al. (2005) Glacier fluctuations, equilibrium-line altitudes and palaeoclimate in Lyngen, northern Norway, during the Lateglacial and Holocene. The Holocene 15(4): 518-540.

Balascio NL and Anderson RS (2016) Paleoenvironmental analysis of Hollabåttjønnen Bog, Skarpeneset Peninsula. In: Nergaard RH (ed.) TØNSNES HAVN, Tromsø Kommune, Troms Rapport Fra de Arkeologiske Undersøkelsene 2014. TROMURA 45. Tromsø: Tromsø Museum, pp. 191-214.

Bell TG (2004) Tollevika, Alta kommune. Rapport. Unpublished excavation report. Tromsø: Tromsø Museum.

Berben SM, Husum K and Aagaard-Sørensen S (2017) A lateHolocene multi-proxy record from the northern Norwegian margin: Temperature and salinity variability. The Holocene 27: 822-834.

Bettinger RL and Grote MN (2016) Marginal value theorem, patch choice, and human foraging response in varying environments. Journal of Anthropological Archaeology 42: 79-87.

Bevan A and Crema ER (2018) Rcarbon v1.2.0: Methods for calibrating and analysing radiocarbon dates. Available at: https://CRAN.R-project.org/package=rcarbon

Binford LR (1980) Willow smoke and dogs' tails: Hunter-gatherer settlement systems and archaeological site formation. American Antiquity 45(1): 4-20.

Binford LR (1990) Mobility, housing, and environment: A comparative study. Journal of Anthropological Research 46(2): $119-152$.

Binford LR (2001) Constructing Frames of Reference: An Analytical Method for Archaeological Theory Building Using Ethnographic and Environmental Data Sets. Berkeley, CA: University of California Press.

Björckl S and Clemmensen LB (2004) Aeolian sediment in raised bog deposits, Halland, SW Sweden: A new proxy record of Holocene winter storminess variation in southern Scandinavia? The Holocene 14(5): 677-688.

Blankholm HP (2011) Plugging the gap: Early metal age in the Ostu mountain pass, Troms, northern Norway. Fennoscandia Archaeologica 28: 19-38.

Borrero LA and Barberena R (2006) Hunter-gatherer home ranges and marine resources: An archaeological case from Southern Patagonia. Current Anthropology 47(5): 855-867.

Büntgen U, Myglan VS, Ljungqvist FC et al. (2016) Cooling and societal change during the Late Antique Little Ice Age from 536 to around 660. Nature Geoscience 9(3): 231-236.

Burch ES (2012) Caribou Herds of Northwest Alaska, 18502000. Fairbanks, AK: University of Alaska Press. Available at: http://www.press.uchicago.edu/ucp/books/book/ distributed/C/bo14275913.html (accessed 20 June 2018).

Butzer KW (2012) Collapse, environment, and society. Proceedings of the National Academy of Sciences 109(10): 36323639.

Cashdan E, Barnard A, Bicchieri MC et al. (1983) Territoriality among human foragers: Ecological models and an application to four bushman groups [and comments and reply]. Current Anthropology 24(1): 47-66.

Chernow YI (1985) The Living Tundra (trans. Löve D). Cambridge: Cambridge University Press.

Contreras DA and Meadows J (2014) Summed radiocarbon calibrations as a population proxy: A critical evaluation using a realistic simulation approach. Journal of Archaeological Science 52: 591-608.
Cooper J and Sheets P (eds) (2012) Surviving Sudden Environmental Change: Answers from Archaeology. Original Edition. Boulder, CO: University Press of Colorado.

Costanza R, Graumlich L, Steffen W et al. (2007) Sustainability or collapse: What can we learn from integrating the history of humans and the rest of nature? Ambio 36(7): 522-527.

Damm CB, Skandfer M, Jørgensen EK et al. (2019) Investigating long-term human ecodynamics in the European Arctic: Towards an integrated multi-scalar analysis of early and midHolocene cultural, environmental and palaeodemographic sequences in Finnmark County, Northern Norway. Quaternary International. Epub ahead of print 26 February. DOI: 10.1016/j.quaint.2019.02.032.

Dawson AG, Elliott L, Mayewski P et al. (2003) Late-Holocene North Atlantic climate 'seesaws', storminess changes and Greenland ice sheet (GISP2) palaeoclimates. The Holocene 13(3): 381-392.

De Vernal A, Hillaire-Marcel C, Rochon A et al. (2013) Dinocystbased reconstructions of sea ice cover concentration during the Holocene in the Arctic Ocean, the northern North Atlantic Ocean and its adjacent seas. Quaternary Science Reviews 79: $111-121$

Desjardins SPA (2013) Evidence for intensive walrus hunting by Thule Inuit, northwest Foxe Basin, Nunavut, Canada. Anthropozoologica 48(1): 37-51.

Drucker P (1951) The Northern and Central Nootkan Tribes. Washington, DC: U.S. Government Printing Office.

Dye T and Komori E (1992) Pre-censal population history of Hawaii. New Zealand Journal of Archaeology 14: 113-128.

Dyer CL (2002) Punctuated entropy as culture-induced change. In: Hoffman SM and Oliver-Smith A (eds) Catastrophe and Culture: The Anthropology of Disaster. Santa Fe, NM: School of American Research Press, pp. 159-185.

Edinborough K, Porčić M, Martindale A et al. (2017) Radiocarbon test for demographic events in written and oral history. Proceedings of the National Academy of Sciences 114(47): 12436-12441.

Engelstad E (1984) Diversity in arctic maritime adaptations: An example from the Late Stone Age of arctic Norway. Acta Borealia 1(2): 3-24.

Engelstad E (1985) The Late Stone Age of Arctic Norway: A review. Arctic Anthropology 22(1): 79-96.

Engelstad E (1988) Pit houses in Arctic Norway: An investigation of the typology using multiple correspondence analysis. In: Madsen T (ed.) Multivariate Archaeology: Numerical Approaches to Scandinavian Archaeology. Aarhus: Jutland Archaeological Society (Jutland Archaeological Society Publications 84), pp. 71-84.

Fitzhugh B (2003) The evolution of complex hunter-gatherers. In: Fitzhugh B (ed.) The Evolution of Complex Hunter-Gatherers. Interdisciplinary Contributions to Archaeology. Boston, MA: Springer, pp. 1-10.

Fitzhugh B (2012) Hazards, impacts, and resilience among hunter-gatherers of the Kuril Islands. In: Cooper J and Sheets P (eds) Surviving Sudden Environmental Change: Answers from Archaeology. Boulder, CO: University of Colorado Press, pp. 19-42.

Fitzhugh B, Gjesfjeld EW, Brown WA et al. (2016) Resilience and the population history of the Kuril Islands, Northwest Pacific: A study in complex human ecodynamics. Quaternary International 419: 165-193.

Forbes BC, Kumpula T, Meschtyb N et al. (2016) Sea ice, rainon-snow and tundra reindeer nomadism in Arctic Russia. Biology Letters 12(11): 20160466.

Forsberg L (2012) Asymmetric twins? Some reflections on coastal and inland societies in the Bothnian area during the Epineolithic and Early Metal Age. In: Anfinset N and Wrigglesworth M (eds) Local Societies in Bronze Age Northern Europe. 
Taylor \& Francis Group, pp. 31-55. Available at: https:// www.taylorfrancis.com/books/e/9781317544111/chapters/10 .4324\%2F9781315728834-11 (accessed 5 March 2018).

Friedrich WL, Kromer B, Friedrich M et al. (2006) Santorini eruption radiocarbon dated to $1627-1600$ B.C. Science 312(5773): $548-548$.

Gräslund B and Price N (2012) Twilight of the gods? The "dust veil event' of AD 536 in critical perspective. Antiquity 86(332): 428-443.

Gronenborn D (2003) Ancestors or chiefs? Comparing social archaeologies in Eastern North America and Temperate Europe. In: Butler BM and Welch PD (eds) Leadership and Polity in Mississippian Society. Carbondale, IL: Southern Illinois University, pp. 365-397.

Grove M (2011) A spatio-temporal kernel method for mapping changes in prehistoric land-use patterns. Archaeometry 53(5): 1012-1030.

Grudd H, Briffa KR, Karlén W et al. (2002) A 7400-year tree-ring chronology in northern Swedish Lapland: Natural climatic variability expressed on annual to millennial timescales. The Holocene 12(6): 657-665.

Hald M, Andersson C, Ebbesen H et al. (2007) Variations in temperature and extent of Atlantic Water in the northern North Atlantic during the Holocene. Quaternary Science Reviews 26(25): 3423-3440.

Halstead P and O'Shea J (1989) Introduction: Cultural responses to risk and uncertainty. In: Halstead P and O'Shea J (eds) Bad Year Economics: Cultural Responses to Risk and Uncertainty. Cambridge: Cambridge University Press, pp. 1-7.

Hamilton MJ, Lobo J, Rupley E et al. (2016) The ecological and evolutionary energetics of hunter-gatherer residential mobility. Evolutionary Anthropology: Issues, News, and Reviews 25(3): 124-132.

Hansen LI (2009) Networks, diversity and mobility among the Northern Sámi in the 16th century. Mémoires de la Société Finno-Ougrienne 265: 217-239.

Hawkes C (1954) Archeological theory and method: Some suggestions from the old world. American Anthropologist 56(2): $155-168$.

Haynes CV (1969) The earliest Americans. Science 166(3906): 709-715.

Helama S and Hood BC (2011) Stone Age midden deposition assessed by bivalve sclerochronology and radiocarbon wiggle-matching of Arctica islandica shell increments. Journal of Archaeological Science 38(2): 452-460.

Helama S, Arppe L, Uusitalo J et al. (2018) Volcanic dust veils from sixth century tree-ring isotopes linked to reduced irradiance, primary production and human health. Scientific Reports 8(1): 1339.

Helama S, Fauria MM, Mielikäinen K et al. (2010) Sub-Milankovitch solar forcing of past climates: Mid and Late-Holocene perspectives. GSA Bulletin 122(11-12): 1981-1988.

Helama S, Holopainen J, Macias-Fauria M et al. (2013) A chronology of climatic downturns through the mid- and late- Holocene: Tracing the distant effects of explosive eruptions from palaeoclimatic and historical evidence in northern Europe. Polar Research 32(1): 15866.

Helama S, Saranpää P, Pearson CL et al. (2019) Frost rings in $1627 \mathrm{BC}$ and AD 536 in subfossil pinewood from Finnish Lapland. Quaternary Science Reviews 204: 208-215.

Helskog K (1980) The chronology of the younger stone age in Varanger, North Norway. Revisited. Norwegian Archaeological Review 13(1): 47-54.

Helskog K (1984) The younger stone age settlements in Varanger, North Norway. Acta Borealia 1(1): 39-70.

Helskog K, Hood BC and Shumkin VY (in press) Dwelling Forms and Settlement Patterns on Russia's Kola Peninsula Coast, 2200-1500 cal. BC. BAR International Series.
Henriksen S (2003) Steinaldergravene i Finnmark. Ei metodisk tilncerming for tolking og gravskikk og religiøse oppfatninger. Hovedfagsoppgave, University of Tromsø, Tromsø.

Henriksen S and Valen CR (2013) Skjærvika og Fjellvika, Hammerfest kommune. Rapport fra de arkeologiske undersøkelsene 2009 og 2010. University of Tromsø. Available at: http://www.ub.uit.no/munin/handle/10037/4871 (accessed 20 March 2017).

Hesjedal A, Damm C, Olsen B et al. (1996) Arkeologi På Slettnes: Dokumentasjon Av 11.000 Ars Bosetning. Tromsø: Tromsø museum. Available at: http://urn.nb.no/URN:NBN:no-nb_ digibok_2011010703008 (accessed 1 March 2017).

Hesjedal A, Ramstad M and Niemi AR (2009) Undersøkelsene på Melkøya : Melkøyaprosjektet - kulturhistoriske registreringer og utgravninger 2001 og 2002. Universitetet i Tromsø. Available at: http://www.ub.uit.no/munin/handle/10037/2437 (accessed 20 March 2017).

Hicks S and Hyvärinen H (1997) The vegetation history of Northern Finland. Helsinki Papers in Archaeology 10: 25-33.

Hodgetts L (2000) Hunting reindeer to support a marine economy. An example from Arctic Norway. Archaeofauna. Available at: https://revistas.uam.es/archaeofauna/article/view/8442 (accessed 21 September 2018).

Hodgetts L (2010) Subsistence diversity in the Younger Stone Age landscape of Varangerfjord, northern Norway. Antiquity 84(323): 41-54.

Høilund Nielsen K (2005) '...the sun was darkened by day and the moon by night...there was distress among men...' - On social and political development in 5th- to 7th-century southern Scandinavia. Studien Zur Sachsenforschung 15: 247-285.

Holdaway S and Porch N (1995) Cyclical patterns in the pleistocene human occupation of Southwest Tasmania. Archaeology in Oceania 30(2): 74-82.

Holmblad P (2010) Coastal communities on the move: House and polity interaction in Southern Ostrobothnia 1500 BC-AD 1. DiVA. Available at: http://urn.kb.se/resolve?urn=urn:nbn:se:u mu:diva-35857 (accessed 15 May 2018).

Holopainen J and Helama S (2009) Little Ice Age Farming in Finland: Preindustrial agriculture on the edge of the Grim Reaper's Scythe. Human Ecology 37(2): 213-225.

Hood BC (1995) Circumpolar comparison revisited: HunterGatherer complexity in the North Norwegian Stone Age and the Labrador Maritime Archaic. Arctic Anthropology 32(2): 75-105.

Hood BC (2015) Framing Sámi entanglement in early modern colonial processes: Ethnohistorical and archaeological perspectives from interior north Norway. Arctic Anthropology 52(2): 37-56.

Hood BC (2016) Chrono-spatial Frameworks and Interpretation in North Norwegian Stone Age Prehistory. Tromsø: University of Tromsø.

Hood BC (2019a) Settlement models for interior Finnmark. In: Skandfer M, Blankholm HP and Hood BC (eds) ArchaeologicalPerspectives on Hunter-Gatherer Landscapes and Resource Management in Interior North Norway. Sheffield and Bristol, CT: Equinox Publishing, pp. $1-44$.

Hood BC (2019b) The Gressbakken Phase: 'Complex' HunterGatherers in Northern Norway? A Case-Study in Archaeological Interpretation (Version of 23 March 2017). Unpublished manuscript, University of Tromsø, Tromsø, 18 January.

Hood BC and Helama S (2010) Karlebotnbakken reloaded: Shifting the chronological significance of an iconic late stone age site in Varangerfjord, North Norway. Fennoscandia Archaeologica 27: 35-43.

Hood BC and Melsæther SG (2016) Shellfish exploitation in Stone Age Arctic Norway: Procurement patterns and household activities. Acta Borealia 33(1): 1-29. 
Hop H (2016) Asbestos Ceramics along the West Norwegian Coast - Influences, Age and Morphology in the Bronze Age/ Early Pre-Roman Iron Age (ca. 1700-400 BC). In: Petterson PE (ed.) Prehistoric Pottery across the Baltic: Regions, Influences and Methods. BAR International Series 2785, pp. 3-12. Available at: https://www.academia.edu/23937650/ Asbestos_Ceramics_along_the_West_Norwegian_Coast Influences_Age_and_Morphology_in_the_Bronze_Age_ Early_Pre-Roman_Iron_Age_ca._1700_400_BC_.In_Petterson_Paul_Ek1\%C3\%B6v_ed. Prehistoric_Pottery Across_the_Baltic_Regions_Influences_and_Methods. BAR_International_Series_2785_2016_p. $\overline{3}-12$ (accessed 18 October 2018).

Horwell CJ and Baxter PJ (2006) The respiratory health hazards of volcanic ash: A review for volcanic risk mitigation. Bulletin of Volcanology 69(1): 1-24.

Horwell CJ, Baxter PJ and Kamanyire R (2015) Health impacts of volcanic eruptions. In: Vye-Brown C, Brown SK, Sparks $\mathrm{S}$ et al (eds) Global Volcanic Hazards and Risk. Cambridge: Cambridge University Press, pp. 289-294.

Huhtamaa H and Helama S (2017) Distant impact: Tropical volcanic eruptions and climate-driven agricultural crises in seventeenth-century Ostrobothnia, Finland. Journal of Historical Geography 57(Suppl. C): 40-51.

Hurrell JW (1995) Decadal Trends in the North Atlantic Oscillation: Regional Temperatures and Precipitation. Science 269(5224): 676-679.

Husum K and Hald M (2004) A continuous marine record 80001600 cal. yr BP from the Malangenfjord, north Norway: Foraminiferal and isotopic evidence. The Holocene 14(6): 877-887.

Jenkins SF, Wilson TM, Magill C et al. (2015) Volcanic ash fall hazard and risk. In: Vye-Brown C, Brown KS, Sparks S et al. (eds) Global Volcanic Hazards and Risk. Cambridge: Cambridge University Press, pp. 173-222.

Jensen C and Vorren K-D (2008) Holocene vegetation and climate dynamics of the boreal alpine ecotone of northwestern Fennoscandia. Journal of Quaternary Science 23(8): 719-743.

Johansen E and Odner K (1968) Arkeologiske undersøkelser på Mortensens ved Varangerfjorden. Viking 32: 57-84.

Jørgensen EK (2018) The palaeodemographic and environmental dynamics of prehistoric Arctic Norway: An overview of human-climate covariation. Quaternary International. Epub ahead of print 14 May. DOI: 10.1016/j.quaint.2018.05.014.

Karlsson H, Hörnberg G, Hannon G et al. (2007) Long-term vegetation changes in the northern Scandinavian forest limit: A human impact-climate synergy? The Holocene 17(1): 37-49.

Keeley LH (1988) Hunter-gatherer economic complexity and 'population pressure': A cross-cultural analysis. Journal of Anthropological Archaeology 7(4): 373-411.

Kelly DRL (2013) The Lifeways of Hunter-Gatherers: The Foraging Spectrum. 2nd Revised Edition. Cambridge: Cambridge University Press.

Kelly RL (1983) Hunter-gatherer mobility strategies. Journal of Anthropological Research 39(3): 277-306.

Kirch PV (1980) The archaeological study of adaptation: Theoretical and methodological issues. Advances in Archaeological Method and Theory 3: 101-156.

Kojola I, Huitu O, Toppinen K et al. (2006) Predation on European wild forest reindeer (Rangifer tarandus) by wolves (Canis lupus) in Finland. Journal of Zoology 263(3): 229-235.

Kolpakov E and Murashkin A (2016) Early Metal Age Dwellings in Eastern Lapland: Investigations of the Kola Archaeological Expedition (IHMC) in 2004-2014. New Sites, New Methods. Available at: https://www.academia.edu/31826221/ Early_Metal_Age_Dwellings_in_Eastern_Lapland_Investigations_of_the_Kola_Archaeological_Expedition_IHMC_ in_2004_2014 (accessed 20 September 2018).
Lamb CT, Mowat G, McLellan BN et al. (2017) Forbidden fruit: Human settlement and abundant fruit create an ecological trap for an apex omnivore. Journal of Animal Ecology 86(1): $55-65$.

Lamnidis TC, Majander K, Jeong C et al. (2018) Ancient Fennoscandian genomes reveal origin and spread of Siberian ancestry in Europe. bioRxiv: 285437. DOI: 10.1101/285437.

Larsen G, Newton AJ, Dugmore AJ et al. (2001) Geochemistry, dispersal, volumes and chronology of Holocene silicic tephra layers from the Katla volcanic system, Iceland. Journal of Quaternary Science 16(2): 119-132.

Lavento M (2001) Textile Ceramics in Finland and on the Karelian Isthmus: Nine Variations and Fugue on a Theme of C.F. Meinander. Vammala: The Finnish Antiquarian Society.

Lawson IT, Swindles GT, Plunkett G et al. (2012) The spatial distribution of Holocene cryptotephras in north-west Europe since $7 \mathrm{ka}$ : Implications for understanding ash fall events from Icelandic eruptions. Quaternary Science Reviews 41: 57-66.

Loveluck CP, McCormick M, Spaulding NE et al. (2018) Alpine ice-core evidence for the transformation of the European monetary system, AD 640-670. Antiquity 92(366): 1571-1585.

Löwenborg D (2012) An Iron Age Shock Doctrine Did the AD 536-7 event trigger large-scale social changes in the Mälaren valley area? Journal of Archaeology and Ancient History. Available at: http://www.arkeologi.uu.se/Journal/no-4-lowenborg (accessed 18 January 2019).

Lupo KD (2007) Evolutionary foraging models in zooarchaeological analysis: Recent applications and future challenges. Journal of Archaeological Research 15(2): 143-189.

MacDonald DH and Hewlett B (1999) Reproductive interests and forager mobility. Current Anthropology 40: 501-523.

Martens VV, Myrvoll ER, Bergersen O et al. (2017) InSituFarms. Archaeological Deposits in a Changing Climate Case Bankgohppi, Unjárgga gielda/Nesseby k., Finnmark. NIKU reports 77. Available at: https://niku.brage.unit.no/nikuxmlui/handle/11250/2505881 (accessed 22 July 2017).

Mattisson J, Rauset GR, Odden J et al. (2016) Predation or scavenging? Prey body condition influences decision-making in a facultative predator, the wolverine. Ecosphere 7(8): $\mathrm{e} 01407$.

Metcalfe D and Barlow KR (1992) A model for exploring the optimal trade-off between field processing and transport. American Anthropologist 94(2): 340-356.

Middleton GD (2017) Understanding Collapse: Ancient History and Modern Myths. Cambridge: Cambridge University Press.

Minc LD and Smith KP (1989) The spirit of survival: Cultural responses to resource variability in North Alaska. In: Halstead P and O'Shea JM (eds) Bad Year Economics: Cultural Responses to Risk and Uncertainty. Cambridge: Cambridge University Press, pp. 8-39. Available at: https://www. researchgate.net/publication/259782660_The_Spirit_of_Survival_Cultural_Responses_to_Resource_Variability_in North_Alaska (accessed 19 April 2018).

Mökkönen T (2011) Studies on Stone Age Housepits in Fennoscandia (4000-2000 cal BC): Changes in ground plan, site location and degree of sedentism. Available at: https://helda. helsinki.fi/handle/10138/26492 (accessed 20 April 2018).

Moseley ME (1999) Convergent catastrophe: Past patterns and future implications of collateral natural disasters in the Andes. In: Oliver-Smith A and Hoffman SM (eds) The Angry Earth: Disaster in Anthropological Perspective. London: Routledge, pp. 59-71.

Moseley ME (2002) Modeling protracted drought, collateral natural disaster, and human responses in the Andes. In: Hoffman , Susanna M and Oliver-Smith A (eds) Catastrophe and Culture: The Anthropology of Disaster. School of American Research Advanced Seminar Series. Santa Fe, NM: School of American Research Press, pp. 187-212. 
Murashkin A, Kolpakov EM, Shumkin VY et al. (2016) Kola Oleneostrovskiy Grave Field: A unique burial site in the European Arctic. New Sites, New Methods 21: 187-199.

Myrvoll E (1992) Stil og samfunn. En analyse av materiell symbolisme og sosiale relasjoner i Varanger 2200 f.Kr. - Kr.f. Magisteravhandling. University of Tromsø, Tromsø.

Niemi AR and Oppvang J (2018) Nyelv Nedre Vest, Nesseby k., Finnmark $f$. - Utgravning av hustuft og boplassområde fra yngre steinalder. Tromsø museums rapportserie 46. Tromsø: Tromsø Museum - Universitetsmuseet.

Nordvig M and Riede F (2018) Are there echoes of the AD 536 event in the Viking Ragnarok Myth? A critical appraisal. Environment and History 24(3): 303-324.

Nummedal A (1937) Yngre Stenaldersfunn fra Nyelven of Karlebotn i Øst-finnmark II. In: Universitetets Oldsakssamling Arbok, pp. 1-26.

Olsen B (1994) Bosetning Og Samfunn i Finnmarks Forhistorie. Oslo: Universitetsforl. Available at: http://urn.nb.no/ URN:NBN:no-nb digibok 2013060306066 (accessed 1 March 2017).

Olsen H (1967) Varanger-Funnene IV: osteologisk Materiale : innledning-Fisk -Fugl. Tromsø: Universitetsforlaget.

Oppvang J (2009) Asbestkeramikk fra Slettnes, Finnmark : typologi, teknologi og bruk. Available at: https://munin.uit. no/handle/10037/1929 (accessed 6 March 2018).

Oppvang J (2018) To tufter i Abelsborg. Utgravning av to tidlig metalltidstufter. Available at: https://munin.uit.no/handle/10037/13908 (accessed 11 December 2018).

Oppvang J, Kjellman E and Niemi AR (2018) Skarvbergvika i Porsanger. Undersøkelse av to hustufter fra tidlig metalltid og en nyere tids teltring. Porsanger k., Finnmark f. 12 January. Tromsø Museum - Universitetsmuseet. Available at: https:// munin.uit.no/handle/10037/12091 (accessed 6 March 2018).

Pääkkönen M, Bläuer A, Olsen B et al. (2018) Contrasting patterns of prehistoric human diet and subsistence in northernmost Europe. Scientific Reports 8(1): 1148.

Page AE, Viguier S, Dyble M et al. (2016) Reproductive tradeoffs in extant hunter-gatherers suggest adaptive mechanism for the Neolithic expansion. Proceedings of the National Academy of Sciences 113(17): 4694-4699.

Pearson CL, Brewer PW, Brown D et al. (2018) Annual radiocarbon record indicates 16th century BCE date for the Thera eruption. Science Advances 4(8): eaar8241.

Perner K, Moros M, Lloyd JM et al. (2015) Mid to Late-Holocene strengthening of the East Greenland Current linked to warm subsurface Atlantic water. Quaternary Science Reviews 129: 296-307.

Pilcher J, Bradley RS, Francus P et al. (2005) A Holocene tephra record from the Lofoten Islands, Arctic Norway. Boreas 34(2): 136-156.

Plunkett G and Pilcher JR (2018) Defining the potential source region of volcanic ash in northwest Europe during the Mid- to Late-Holocene. Earth-Science Reviews 179: 20-37.

Price N and Gräslund B (2015) Excavating the Fimbulwinter? Archaeology, Geomythology and the Climate Event(s) of AD 536. In: Riede F (ed) Past Vulnerability. Volcanic Eruptions and Human Vulnerability in Traditional Societies past and Present. Aarhus: Aarhus University Press, pp. 109-132.

Price TD (1991) The view from Europe: Concepts and questions about terminal Pleistocene societies. In: Dillehay TD and Meltzer DJ (eds) First Americans: Search and Research. Boca Raton, FL: CRC Press, pp. 185-208.

R Development Core Team (2015) R: A Language and Environment for Statistical Computing. Vienna: R Foundation for Statistical Computing. Available at: http://www.gbif.org/ resource/81287 (accessed 1 March 2017).

Ramsey CB (2017) Methods for summarizing radiocarbon datasets. Radiocarbon 59(6): 1809-1833.
Redman CL and Kinzig AP (2003) Resilience of past landscapes: Resilience theory, society, and the Longue Durée. Conservation Ecology 7. Available at: https://www.jstor.org/stable/26271922 (accessed 14 December 2018).

Renouf MAP (1984) Northern coastal hunter-fishers: An archaeological model. World Archaeology 16(1): 18-27.

Renouf MAP (1988) Sedentary coastal hunter-fishers: An example from the Younger Stone Age of Northern Norway. In: Bailey G and Parkington J (eds) The Archaeology of Prehistoric Coastlines. Cambridge: Cambridge University Press, pp. 102-115.

Renouf MAP (1989) Prehistoric Hunter-Fishers of Varangerfjord, Northeastern Norway: Reconstruction of Settlement and Subsistence during the Younger Stone Age. Oxford: British Archaeological Reports.

Rick JW (1987) Dates as data: An examination of the Peruvian Preceramic Radiocarbon Record. American Antiquity 52(1): $55-73$.

Riede F (2009a) Climate change, demography and social relations: An alternative view of the Late Palaeolithic pioneer colonization of Southern Scandinavia. In: McCartan S, Woodman P, Schulting R et al . (eds) Mesolithic Horizons: Papers Presented at the Seventh International Conference on the Mesolithic in Europe, Belfast 2005. Oxford: Oxbow Books. Available at: http://discovery.ucl.ac.uk/17793/ (accessed 25 October 2017).

Riede F (2009b) The loss and re-introduction of bow-and-arrow technology: A case study from the Northern European Late Palaeolithic. Lithic Technology 34: 27-45.

Riede F (2019) Doing palaeo-social volcanology: Developing a framework for systematically investigating the impacts of past volcanic eruptions on human societies using archaeological datasets. Quaternary International 499: 266-277.

Riede F and Wheeler JM (2009) Testing the 'Laacher See hypothesis': Tephra as dental abrasive. Journal of Archaeological Science 36(10): 2384-2391.

Riede F, Oetelaar GA and Van der Hoek R (2017) From crisis to collapse in hunter-gatherer societies. A comparative investigation of the cultural impacts of three large volcanic eruptions on past hunter-gatherers. In: Cunningham $\mathrm{T}$ and Driessen $\mathrm{J}$ (eds) Crisis to Collapse - The Archaeology of Social Breakdown. Louvain-la-Neuve: UCL Presses Universitaires De Louvian, pp. 23-39. Available at: http://pure.au.dk/portal/ $\mathrm{da} /$ publications/from-crisis-to-collapse-in-huntergatherersocieties(5cf7289b-3107-4b73-8952-20e1235a9a10).html (accessed 22 February 2018).

Risch R and Meller H (2015) Change and continuity in Europe and the Mediterranean around $1600 \mathrm{BC}$. Proceedings of the Prehistoric Society 81: 239-264.

Robertson BA and Hutto RL (2006) A framework for understanding ecological traps and an evaluation of existing evidence. Ecology 87(5): 1075-1085.

Robinson E and Riede F (2018) Cultural and palaeoenvironmental changes in late glacial to middle Holocene Europe: Gradual or sudden? Quaternary International 465: 159-161.

Rowley-Conwy P and Piper S (2016) Hunter-gatherer variability: Developing models for the northern coasts. Arctic 69(5): $1-14$.

Sarkissian CD, Balanovsky O, Brandt G et al. (2013) Ancient DNA reveals prehistoric gene-flow from Siberia in the complex human population history of North East Europe. PLoS Genetics 9(2): e1003296.

Schanche K (1988) Mortensnes, en boplass i Varanger : en studie av samfunn og materiell kultur gjennom 10.000 år. Available at: http://www.ub.uit.no/munin/handle/10037/3316 (accessed 10 March 2017).

Schanche K (1989) Nye funn fra yngre steinalder i Varanger. Viking LII: 53-71. 
Schanche K (1994) Gressbakkentuftene i Varanger : boliger og sosial struktur rundt $2000 \mathrm{f}$. Kr. Available at: http://www.ub.uit. no/munin/handle/10037/3317 (accessed 10 March 2017).

Schanche K (1995) Var det store landsbyboplasser i Finnmark i yngre steinalder? Debattinnlegg med utgangspunkt i bosetningsspor fra ca. 2000 f.Kr. In: Arkeologiske Skrifter. Bergen: Arkeologisk Institutt Bergen Museum, pp. 174-186. Available at: https://www.nb.no/nbsok/nb/f2ced2fc4cd5c3fd09260 151527ad17a?lang=no (accessed 25 January 2019).

Seitsonen O, Nordqvist K, Gerasimov DV et al. (2012) 'The good, the bad, the weird': Stone Age and Early Metal Period radiocarbon dates and chronology from the Karelian Isthmus, North-West Russia. Geochronometria 39(2): 101-121.

Seppä H, Bjune AE, Telford RJ et al. (2009) Last nine-thousand years of temperature variability in Northern Europe. Climate of the Past 5(3): 523-535.

Sheets P (1999) The effects of explosive volcanism on ancient egalitarian, ranked, and stratified societies in middle America. In:Oliver-Smith A and Hoffman S (eds) The Angry Earth: Disaster in Anthropological Perspective. New York: Routledge, pp. 36-58.

Sheets P (2001) The effects of explosive volcanism on simple to complex societies in ancient Middle America. In: Markgraf V (ed.) Interhemispheric Climate Linkages. San Diego, CA: Academic Press, pp. 73-86.

Sheets P (2012) Responses to explosive volcanic eruptions by small to complex societies in ancient Mexico and Central America. In: Cooper J and Sheets P (eds) Surviving Sudden Environmental Change. Boulder, CO: University Press of Colorado, pp. 43-63.

Shennan S (2013) Demographic continuities and discontinuities in Neolithic Europe: Evidence, methods and implications. Journal of Archaeological Method and Theory 20(2): 300-311.

Shennan S and Edinborough K (2007) Prehistoric population history: From the Late Glacial to the Late Neolithic in Central and Northern Europe. Journal of Archaeological Science 34(8): 1339-1345.

Sigl M, Winstrup M, McConnell JR et al. (2015) Timing and climate forcing of volcanic eruptions for the past 2,500 years. Nature 523(7562): 543-549.

Simonsen P (1961) Varanger-funnene II Fund og udgravninger på fjordens sydkyst. Tromsø Museums Skrifter II. Tromsø: Tromsø Museum.

Simonsen P (1964) Steinalderundersøkelser på Sørøy i Vest-Finnmark. Håløygminne Hefte 1: 1-11.

Simonsen P (1972) The transition from food-gathering to pastoralism in North Scandinavia and its impact on settlement patterns. In:Ucko P (ed.) Man, Settlement and Urbanism. London: Duckworth, pp. 187-192.

Simonsen P (1979) Veidemenn på Nordkalotten. Hefte 3: Yngre steinlader og overgang til tdlig metall tid. Stensilserie B-Historie 17. Tromsø: Institutt for samfunnsvitenskap, Universitetet i Tromsø.

Simonsen P (1996) Steinalderbosetningen i sandbukt på Sørøya, Vest-Finnmark: rapport og tolkning. Tromsø: Tromsø Museum.

Sjögren P and Damm C (2019) Holocene vegetation change in northernmost Fennoscandia and the impact on prehistoric foragers 12 000-2000 cal. a BP - A review. Boreas 48(1): 20-35.

Sjögren P, Karlsen SR and Jensen C (2015) The use of quantitative models to assess long-term climate-vegetation dynamics - A case study from the northern Scandinavian Mountains. The Holocene 25(7): 1124-1133.

Skandfer M (2012) Change and Recollection: House Structures and Social Identification in Finnmark, Arctic Norway. In: Damm CB and Saarikivi J (eds) Networks, Interaction and Emerging Identities in Fennoscandia and Beyond. Papers from the Conference held in Tromsø, Norway, October 13-16,
2009. Suomalais-Ugrilainen Seura / Finno-Ugrian Society, pp. $155-176$.

Skandfer M, Blankholm HP and Hood BC (2019) Archaeological Perspectives on Hunter-Gatherer Landscapes and Resource Management in Interior North Norway. Sheffield and Bristol, CT: Equinox Publishing.

Smith CS and McNees LM (1999) Facilities and hunter-gatherer long-term land use patterns: An example from Southwest Wyoming. American Antiquity 64(1): 117-136.

Smith EA (1991) Inujjuamiut Foraging Strategies: Evolutionary Ecology of an Arctic Hunting Economy. 1st Edition. New York: Aldine Transaction.

Solich M and Bradtmöller M (2017) Socioeconomic complexity and the resilience of hunter-gatherer societies. Quaternary International 446: 109-127.

Spiess AE (1979) Reindeer and Caribou Hunters: An Archaeological Study. New York: Academic Press.

Stenton DR (1991a) Caribou population dynamics and thule culture adaptations on Southern Baffin Island, N.W.T. Arctic Anthropology 28(2): 15-43.

Stenton DR (1991b) The adaptive significance of caribou winter clothing for arctic hunter-gatherers. Études/Inuit/Studies 15(1): 3-28.

Sundqvist HS, Kaufman DS, McKay NP et al. (2014) Arctic Holocene proxy climate database - New approaches to assessing geochronological accuracy and encoding climate variables. Climate of the Past 10(4): 1605-1631.

Surovell TA (2000) Early palaeoindian women, children, mobility, and fertility. American Antiquity 65: 493-508.

Surovell TA and Brantingham PJ (2007) A note on the use of temporal frequency distributions in studies of prehistoric demography. Journal of Archaeological Science 34(11): 1868-1877.

Surovell TA, Byrd Finley J, Smith GM et al. (2009) Correcting temporal frequency distributions for taphonomic bias. Journal of Archaeological Science 36(8): 1715-1724.

Suttles W and Sturtevant W (eds) (1990) Handbook of North American Indians, Vol. 7: Northwest Coast. 1st Edition. Washington, DC: Smithsonian Institution Scholarly Press.

Swindles GT, Lawson IT, Savov IP et al. (2011) A 7000 yr perspective on volcanic ash clouds affecting northern Europe. Geology 39(9): 887-890.

Tallavaara M and Pesonen P (2018) Human ecodynamics in the north-west coast of Finland 10,000-2000 years ago. Quaternary International. Epub ahead of print 22 June. DOI: 10.1016/j.quaint.2018.06.032.

Tallavaara M and Seppä H (2012) Did the mid-Holocene environmental changes cause the boom and bust of hunter-gatherer population size in eastern Fennoscandia? The Holocene 22(2): 215-225.

Tallavaara M, Eronen JT and Luoto M (2018) Productivity, biodiversity, and pathogens influence the global hunter-gatherer population density. Proceedings of the National Academy of Sciences 115(6): 1232-1237.

Tallavaara M, Luoto M, Korhonen N et al. (2015) Human population dynamics in Europe over the Last Glacial Maximum. Proceedings of the National Academy of Sciences 112: 8232-8237.

Tallavaara M, Pesonen P and Oinonen M (2010) Prehistoric population history in eastern Fennoscandia. Journal of Archaeological Science 37(2): 251-260.

Timpson A, Colledge S, Crema E et al. (2014) Reconstructing regional population fluctuations in the European Neolithic using radiocarbon dates: A new case-study using an improved method. Journal of Archaeological Science 52: 549-557.

Tipping R, Bradley R, Sanders J et al. (2012) Moments of crisis: Climate change in Scottish prehistory. Proceedings of the Society of Antiquaries of Scotland 142: 9-25. 
Toohey M, Krüger K, Sigl M et al. (2016) Climatic and societal impacts of a volcanic double event at the dawn of the Middle Ages. Climatic Change 136(3): 401-412.

Torrence R (2019) Social responses to volcanic eruptions: A review of key concepts. Quaternary International 499: 258-265.

Tremayne AH and Brown WA (2017) Mid to Late-Holocene population trends, culture change and Marine Resource Intensification in Western Alaska. Arctic 70(4): 365-380.

Tremayne AH and Winterhalder B (2017) Large mammal biomass predicts the changing distribution of hunter-gatherer settlements in mid-Late-Holocene Alaska. Journal of Anthropological Archaeology 45(Suppl. C): 81-97.

Turunen MT, Rasmus S, Bavay M et al. (2016) Coping with difficult weather and snow conditions: Reindeer herders' views on climate change impacts and coping strategies. Climate Risk Management 11: 15-36.

Tvauri A (2014) The Impact of the Climate Catastrophe of 536$537 \mathrm{AD}$ in Estonia and Neighbouring Areas/536.-537. Aasta Kliimakatastroofi Moju Eestis Ja Naaberaladel. Estonian Journal of Archaeology 18(1): 30.

Tyler NJC (2010) Climate, snow, ice, crashes, and declines in populations of reindeer and caribou (Rangifer tarandus L.). Ecological Monographs 80(2): 197-219.

VanderHoek R and Nelson RE (2007) Ecological roadblocks on a constrained landscape: The cultural effects of catastrophic holocene volcanism on the Alaska Peninsula, Southwest Alaska. In: Grattan J and Torrence R (eds) Living Under the Shadow. Cultural Impacts of Volcanic Eruptions. Walnut Creek, CA: Left Coast Press, pp. 133-152.

Vaneeckhout S (2010) House societies among coastal huntergatherers: A case study of Stone Age Ostrobothnia, Finland. Norwegian Archaeological Review 43(1): 12-25.

Venkataraman VV, Kraft TS, Dominy NJ et al. (2017) Huntergatherer residential mobility and the marginal value of rainforest patches. Proceedings of the National Academy of Sciences 114(12): 3097-3102.

Voronina E, Polyak L, Vernal AD et al. (2001) Holocene variations of sea-surface conditions in the southeastern Barents
Sea, reconstructed from dinoflagellate cyst assemblages. Journal of Quaternary Science 16(7): 717-726.

Vorren K-D, Blaauw M, Wastegård S et al. (2007) High-resolution stratigraphy of the northernmost concentric raised bog in Europe: Sellevollmyra, Andøya, northern Norway. Boreas 36(3): 253-277.

Vorren K-D, Jensen CE and Nilssen E (2012) Climate changes during the last c. 7500 years as recorded by the degree of peat humification in the Lofoten region, Norway. Boreas 41(1): 13-30.

Wastegård S, Andersson S and Perkins VH (2009) A new midHolocene tephra in central Sweden. GFF 131(4): 293-297.

Watson EJ, Swindles GT, Lawson IT et al. (2016) Do peatlands or lakes provide the most comprehensive distal tephra records? Quaternary Science Reviews 139: 110-128.

Watson EJ, Swindles GT, Savov IP et al. (2017) Estimating the frequency of volcanic ash clouds over northern Europe. Earth and Planetary Science Letters 460: 41-49.

Weiss H and Bradley RS (2001) What drives societal collapse? Science 291(5504): 609-610.

Whallon R (2006) Social networks and information: Non'utilitarian' mobility among hunter-gatherers. Journal of Anthropological Archaeology 25(2): 259-270.

Williams AN (2012) The use of summed radiocarbon probability distributions in archaeology: A review of methods. Journal of Archaeological Science 39(3): 578-589.

Wilson TM, Jenkins SF and Stewart C (2015) Volcanic ash fall impacts. In: Vye-Brown C, Brown SK, Sparks S et al. (eds) Global Volcanic Hazards and Risk. Cambridge: Cambridge University Press, pp. 281-288.

Wittmeier HE, Bakke J, Vasskog K et al. (2015) Reconstructing Holocene glacier activity at Langfjordjøkelen, Arctic Norway, using multi-proxy fingerprinting of distal glacier-fed lake sediments. Quaternary Science Reviews 114: 78-99.

Zeidler JA (2016) Modeling cultural responses to volcanic disaster in the ancient Jama-Coaque tradition, coastal Ecuador: A case study in cultural collapse and social resilience. Quaternary International 394: 79-97. 